\title{
SÜRDÜRÜLEBİLİR REKABETTE TEMEL YETENEKLER: ISPARTA KEBAPÇI ESNAFI/LOKANTA İŞLETMELERINDE ARAŞTIRMA
}

\section{Nurhan PAPATYA}

Prof. Dr. SDÜ, İiBF, İşletme Öğretim Üyesi, Çünür Doğu Kampusu 32260 Isparta e-posta.nurhanpapatya@sdu.edu.tr

\section{Gürcan PAPATYA}

Doç. Dr. SDÜ, İiBF, İşletme Öğretim Üyesi, Çünür Doğu Kampusu 32260 Isparta gurcanpapatya@sdu.edu.tr

\section{İlbey Kutluhan PAPATYA}

MAKÜ, SBE YL, İstiklal Yerleşkesi 15030 Burdur e-posta. kpapatya@gamil.com 
Sürdürülebilir Rekabette Temel Yetenekler: Isparta Kebapçı Esnafi/Lokanta İşletmelerinde

\title{
SÜRDÜRÜLEBILLIR REKABETTE TEMEL YETENEKLER: ISPARTA KEBAPÇI ESNAFI/LOKANTA ISSLETMELERINDE ARAŞTIRMA
}

\section{Özet}

Bu makale, Türk lokanta işletmeciliği ve Isparta ili geleneksel kebapçı esnafi/lokanta işletmelerinin ve aşçlık mesleğinin sürdürülebilir rekabet anlayışını ve bu anlayışa yön veren temel yeteneklerin incelenmesine yönelik karma bir araştırmadır. Araştırma uygunluk örneklemi yoluyla belirlenen ve eşzamanlı dönüşümsel tasarım ile kadim kebapçılar olarak nitelenen, kuruluş tarihleri en az bir asra dayanan, atadan işletmeci üç kebapçı esnafi/lokanta işletmesi üzerinde gözlem, görüşme ve derinliğine mülakat tekniklerini içeren etnografik temelli nitel ve anket tekniği ile nicel analizi kapsar. Araştırmanın nitel bulguları, sözel tarihleme yöntemi ile irdelenmiş, nicel bulgularla desteklenmiş̧ir. Araştırma sonucunda kebapçı esnafi/lokanta işletmelerinin sürdürülebilir rekabet için daha fazla çaba göstermesi gerektiği tespit edilmiştir.

Anahtar Kavramlar: Sürdürülebilir Rekabet, Temel Yetenekler, Türk-Anadolu Mutfak Kültürü, Lokanta İşletmeleri, Isparta Kebapçı esnafi/lokanta işletmeleri, Karma Araştırma.

Jel Kodu: M3, M31.

\section{CORE COMPETENCE IN SUSTAINABLE COMPETITION: RESEARCH IN ISPARTA KEBAB TRADER/RESTAURANT BUSINESS}

\begin{abstract}
This article is a mixed study to examine the understanding of sustainable competition of Turkish restaurant management and traditional kebab trader/restaurant businesses in Isparta and the cookery profession and the core competence that guide this understanding. The research is based on three ancestral business manager's kebab trader/restaurant businesses, whose establishment dates back at least one century, and are defined as ancient kebab restaurants with simultaneous transformational design; it covers ethnographically based qualitative and questionnaire techniques and quantitative analysis including observation, interview and indepth interview techniques. The qualitative findings of the research were examined with the verbal dating method and supported with quantitative findings. As a result of the research, it was determined that the kebab trader/restaurant businesses should make more efforts for sustainable competition.
\end{abstract}

Key Concepts: Sustainable Competition, Core Competence, Turkish-Anatolian Cuisine Culture, Restaurant Businesses, Isparta Kebap Trader/Restaurant Business, Mix Research.

Jel Code: M3, M31.

Açıklayıcı Not. Makale boyunca, cümle sonunda nokta dışı verilen atıflar [daha ziyade $b k z$. ve/veya ayrıca bkz. biçimli] ana bilgiyi destekleyici; nokta içi verilen atıflar, alıntılama ya da tanımlayıcı ve çeviri atıflar biçiminde iki yönlü verilmiştir. Ayrıca makale metininde [ ] şeklinde yazımlar, metin bütünlüğünde anlam peşiktirici, ( ) içinde kelime, terim, deyim vs. İngilizce mütekabili ve açıklaması olarak yazılmıştır. Özgün ya da üzerinde durulması gereken kavramsallarda, ya "tırnak" içinde veya eğri (italik) olarak vurgulanmıştır. 


\section{Giriș: Genel Olarak Lokanta İşletmeciliği ve Așçılık Mesleği}

Lokanta işletmeciliğgi ve/veya işletmelerinin köken düşüncesi aşçılık mesleği, bilimsel olarak Asurlulara kadar götürülebilir: (bkz. Câhız, 1999: 75) Asurlularda toplum yaşantısının bir parçası olarak aşçılık, varsıl-üst tabaka mutfak/yemek kültürünün bir parçası ve süreklilik arz eden çeşitli meslek gruplarından biri olarak değerlendirilir ve yemek satıcılı̆̆ına dair ticari bir faaliyeti niteler. ${ }^{1}$

Yazında özellikle çarşı ve pazarlarda, evinden uzak işyeri olanlara/esnafa lokantalarda (havânîtü'l tabbbâhîn) yemek satıldığı ve hizmet sunulduğuna yönelik kayıtlardan söz edilir. $^{2}$ Ancak modern anlamda bağımsız çalışma koşullarının oluşması ile aşçılık mesleğinin hazır yemek satıcılığı veya lokanta işletmelerinin dönüşümü çok yakın geçmişe ilişkin değerlendirilmektedir:

Lokanta işletmelerinden/restoranlardan ${ }^{3}$ hazır yemek satın alma eğilimi 18.yy’dan sonra şekillendiği izlenmektedir. Lokanta işletmeleri, insanların gün içinde kaybolan enerjilerinin [özellikle tanrıları güçlendirici onarıcı (restorative) et suyu satan Parisli Baulanger'den bu yana] geriye kazandığı, bol baharatlı yemeklerin yendiği imtiyazlı bir konumlandırmadan çok daha ötede değerlendirilmektedir. (bkz. https://digital.library.unlv.edu/collections/menus /history-restaurant) Diğer bir deyişle insanların değişen yaşantı tarzları içinde lokanta işletmelerinin yeri, imtiyazlı olma göstergesi olarak biçimlenmesi, iş bitirme, iş görme veya iş başarma yolunu açan [araçsal-bağlamsal] bir sistemin parçası olarak görülmektedir. Bu nedenle lokanta işletmelerinin iş ve toplumsal hayata ilişkin çok boyutlu dönüştürücü rolü, itibarî ve ticarî bir faaliyet olarak karşımıza çıkar. Yani lokanta işletmeleri insanların değişen yaşantılarında hayatta tutunmak için olağan, gerçek ve yaygın işlev açlığı bastırmaktan ve karın doyurmaktan daha ötede bir işlev görür. (yemeğin sosyolojisi dair ayrıca bkz. Beşirli, 2021; Beardsworth, Keil, 2012)

İnsanların yaşantı tarzlarındaki değişim ve yemek yapmaya vakit bulmakta zorlanması ya da yemek pişirmekle uğraşmak istememesi, doğal olarak lokanta işletmelerinde hazır yapılmış yemeğe olan ilgiyi artırır. (hayat tarzl, tüketim kültürü ve teorilerine ilişkin bkz. Featherstone, 1996: 36-58 ve 141-158) Bu durum yemek tüketim biçimlerinin ve yemek türlerinin yeniden tasarlanmasını da teşvik eder. Ancak geleneksel ilgilerini ve tutumlarını sürdüren insanların lokanta işletmelerine olan bakış tarzının tamamen olumlu olduğu söylenemez. Özellikle dışarıdan yemek satın almanın veya lokanta işletmesine gitmenin zorunluluk olmaksızın alışkanlık haline gelmesi, toplum mutfak kültürünün ve yemek yeme değerlerinin yozlaşması, aile ikliminin zedelenmesi ve/hatta bireylerin topluma ve kendine yabancılaşması sorunu tartışılmaktadır. (bkz. Douglas, Isherwood, 1998)

\footnotetext{
${ }^{1}$ Keza, erişilebilen kaynaklara göre sözgelişi Avrupa'da ticari bir faaliyet olarak aşçılık mesleği, lokantacılık ve yemek satıcılığı, Arap ve Emevi toplumları ile birlikte taşındığı iddia edilmektedir. bkz. Altınay, 2006

${ }^{2} \mathrm{Bu}$ devlet düzeyinde, sözgelimi Türk Memluklu Devleti'nde de devlet erkânına yemek hizmeti sunan, yemek işlerinden ve teşrifatından sorumlu özel birimler (havâichâne) oluşturulduğu ifade edilir. bkz. Altan, 2006: 107-117.

${ }^{3}$ Restoran Fransızca "restore" kelimesinden gelen, yeniden düzenlemek, formuna sokmak anlamındadır. Buna göre restoran aç mideleri doyurup, insanları onarma (restore etme) anlamı taşıyan bir işletme türüdür. $b k z$.

https://www.oxfordlearnersdictionaries.com/definition/english/restaurant?q=restaurant;

https://www.nisanyansozluk.com/?k=restaurant
} 
Bu konuda tüm söylenenlerin/söyleneceklerin haklı bir yanı bulunabilir; çünkü toplumlarda mutfak/yemek kültürünün sadece yeme-içme ile sınırlı olmadığı açıktır. Sınırsızlığı, çok farklı alt/yan kültürler (subculture) veya farklı yemek kültürleri ile beraber düşünmek gerekir. (Türk-Anadolu mutfak/yemek kültürü bă̆lamında bkz. Kaya, 2017; Eksen 2008) Yani yemekten sorumlu olan kişilerden, yemeğin pişirildiği yere, yenen yemeğe, yemekte oturulan yere, kullanılan yemek alet edevatına, yenilen yiyeceğin türüne, yemek satın alanlara ve diğer ilgilere kadar yaşanan tedrici hareketlilik mutfak/yemek kültürünün bir parçasını oluşturur. (Altan, 2006: 108; Brillat-Savarin, 2016) Hatta bu ifadelere bağlı olarak, "mutfak/yemek kültürü ideolojisi”nin yapılması gerektiğini söylenir. Çünkü yemek yeme mekânları ve yemekler, aynı zamanda bir kültürel ideolojinin aşılama aracı olarak değerlendirilmektedir. (bkz. Boudan, 2004; ayrıca bkz. Ranta, Ichijo, 2015)

Elbette bu tartışmalar sürecektir. Ancak, lokanta işletmelerin 16.yy'daki [Batı aristokrat saltanatının bir yansıması olarak] "sanki özel odalarda" yemek yenen yer olmaktan çıkıp, toplumun geneline yayılan ve sadece güçlendirici yiyeceklerin satılmadığı mekânlar olarak hayatın tam merkezinde yer alan bir kavram haline geldiği aşikârdır. Bu durum, zamanla değişen/dönüşen lokanta işletmeleri/işletmeciliği kavramının sadece yemek yenilen yer olmaktan çıkıp, bir şeyler içme ${ }^{4}$ ve sosyal yönün keşfini sağlama, sosyal statü, güç ilişkileri ve grup kimliğini belirtme gibi daha özel ve yeni işlevselliği de ortaya çıkarır. Böylece bir varlık/hayat sebebi ve alanı olan yemek yeme, bilgibiçimsel (epistemolojik) olarak daha geniş bir bilişim kaynağı oluşturmuş olmaktadır: (siyaset ve simgecilik açısından yemek yeme çözümlemesi için bkz. Artun, 2020) Yani orta çağların sembolize edici aklı, yemek konusunda da devreye girerek, pek çok sembolik anlamı yemek konusuna da rahatça yüklediği görülür. Temsil ettiği hakikatin soyut doğasını sembolleştirme çalışmaları ile farklı gerçekliklere konu oluşturur. $\mathrm{Bu}$ nedenle lokanta işletmelerinde yemek konusunu ele almak, sadece yenilen-içilenlerin istatistiğini yapmanın ötesinde, barındırdığı (tazammun ettiği) muhtelif alanları (sembolik anlamlarla beraber) ilgilendiren bilgi bölüklerini erişme ve başka konulara dair birçok bilgiyi de öğrenmek anlamına gelmektedir (Altan, 2006: 115). Dahası, lokanta işletmelerinin -kısa süreli de olsa- insanların vakitlerini sosyal gelişme için değerlendirdiği, başka insanlarla projelerini tartıştı̆̆ı, fikirlerini görücüye çıkardığı yeni yaşantıbiçim (new lifestyle) platformları ve sunum mekânları olduğunu düşündürebilir. ${ }^{5}$

\footnotetext{
${ }^{4} \mathrm{Bu}$ yönde kafeler, sadece insanların çay-kahve gibi içecekleri içtikleri yer değil, bir şeylerin yendiği, keyif sürmek için gidilen yerler olmuştur. Bu bağlamda dünyada ilk defa kafe 1550 yılında İstanbul'da açılmıştır. bkz. Bingöl, 2005: 25; ayrica bkz. Heller, 2000: 171-175.

${ }^{5}$ Şu da not olarak düşülebilir: Lokanta işletmelerinin yeni işlevselliği, “yemek yenen yerlerin dönüşümü” açısından oldukça önemli bir konu olarak yorumlanabilir. Fiziksel ihtiyaçtan öte, sosyal-ruhsal bir ihtiyaç olarak lokantaların bu işlevselliği, doğal olarak lokantaları ev yemeklerinin bulunduğu, makul fiyatlarla satın alındığı, ev sıcaklığında ve özgün yerler haline gelmesine yol açtığı söylenebilir. Hatta yaşantının belirli bölümlerinde mekânsal özelliklerin dışına çıkılarak, yemek vagonları ve diğer seyyar ortamların lokanta işletmelerinin alternatifi olarak sunma faaliyetlerine de rastlamak mümkündür. Sözgelimi, 1880'li yıllarda İngiltere'de trenlerde müşterilerin içinde ayak-üstü yemek yedikleri, hatta oturdukları seyyar yerler oluşturulmuş; özellikle işten eve olan mesafenin çok olduğu yerlerde, daha ucuz ve kolay erişebilecek olanaklar sunulmuştur. Ayrıca yoğun insan trafiğine bağlı, müşterilerin kendi yemeklerini almaları (selfservis), gereği kadar hizmetin etkin verilmediği durumlarda kabul görmüştür. Böylece hem daha az maliyetle çalışma, hem de yüksek kârlılık amaçlanmıştır. Daha ileride, 20.yüzyılın başlarında "otomat"lar ile yaşanan yöneliş lokanta işletme faaliyetlerine yeni bir boyut kazanmasına da zemin hazırlamışıı. 1912 yılında ABD'de Brodway'in Times Meydanı'nda, mermer masalar ve mozaik fayanslı döşemeler ile şatafatlı bir yer izlenimi veren ilk New-York Horn-Hardart Otomat'1 açılması örnek gösterilebilir. Hazır ve basit yemekler yeme sıradanlığını yücelten, kendi kendine hizmet çılgınlığının doruk noktasını oluşturur. Ayrıca durumu Prof. Dr. Ortaylı şu veciz cümle ile ifade eder: "İyi yemek yapmak bir kültür
} 
Bu keskin ve sıklıkla yaşanan düşünce, bir anlamda lokanta işletmeciliğinin yeni koşullara uyum sağlama, değişme ve/hatta dönüşme ihtiyacını gösterir. Lokanta işletmelerine yönelik yeni işlevsellikler de, insanların yeme ihtiyaçlarını karşılamaktan ziyade, stratejik mekân tercihi olarak yeni bir düşüncenin ürünü yapmış olur. Artık bugün lokanta işletmeleri tüm yönleri ile profesyonel [hizmet] işletmeler olarak stratejik ilhamına veya geleceğe özgü duyuş ve düşünceye erişme olanağı bulduğu söylenebilir.

Özetle günümüz lokanta işletmeciliğinin, (a) seçkin (elite) sınıfın iyi hizmet, kaliteli yemek ve bağlı [müşteri] hoşnutluğun yüksek para vererek satın alındığı ve sosyalleştiği, (b) ve halkın yüksek tempoda devam eden yaşantısını dengelemeye ilişkin daha mütevazı paralarla karnını doyurduğu mekânlar olarak üstelenen çift yönlü işlevsel rolü ötesinde, stratejik/ideolojik bir kimliklendirmeyi de nitelediği düşünülebilir.

\section{Türk-Anadolu Mutfak/Yemek Kültürü: Lokanta İşletmeciliği olarak Kebapçılık}

(a) Türk-Anadolu Mutfak/Yemek Kültürü: Türk-Anadolu mutfak/yemek kültürü, tarihsel süreçte Türklerin Orta Asya'dan çıkışı ile günümüze doğru evrilimi ve olgunlaşması şeklinde kendini gösterir. Asya ve Anadolu topraklarının sunduğu çeşitli olanaklar, tarihsel bağlamsallıkta diğer kültürlerle yaşanan etkileşim, yakın Türk tarihinde Selçuklu ve Osmanlı saraylarında gelişen tatların varlığı, İslam dininin etkisiyle Arap ve Fars mutfağının ve Mezopotamya'dan kaynaklanan mutfak varlığı, Türk-Anadolu mutfağının renkliliğini ve çeşit zenginliğini oluşturur. (bkz. Baysal vd., 1996; Işın, 2018; Işın, 2017; Işın, 2014) Özellikle Orta Asya göçer insanının et ve mayalanmış süt ürünleri kullanımı, Mezopotamya'nın tahılları, Akdeniz çevresinin sebze ve meyveleri, Güney Asya'nın baharatı ile birlikte kullanılarak zengin Türk mutfak/yemek kültürü oluşumuna katkı verir (Baysal, 1993: 12-20). Ege Adalarından ve kıyılarından balık ile zeytinyağ1, güney bölgesinden şerbetli tatlılar, Bizans'tan Roma mutfağını adeta bir potada eritir. (bkz. Dalby, 2014) Özellikle Osmanlı İmparatorluğunun geniş topraklara yayılması ile birlikte Ortadoğu, Güney Akdeniz ve Avrupa yemekleri de bu potaya girerek Türk-Anadolu Mutfağı'nı daha da geliştirip zenginleştirdiği ifade edilir (Gürsoy, 1995; Işın, 2018). Bu nedenle gastronomi uzmanlarına göre, Türk-Anadolu yemek aşçılığ1 ve mutfalk kültürü dünyanın temel ve en gelişmiş mutfakları arasında yer almaktadır. (bkz. Güler, 2010: 24-30; ayrica bkz. Yerasimos, 2005)

$\mathrm{Bu}$ çerçevede modern Türk-Anadolu yemek aşçılığı/lokanta işletmeciliği tarihi, Osmanlı imparatorluğu zamanında daha sistemli ve daha gelişmiş olduğu bulgulanabilir. ${ }^{6}$ Yani modern Türk-Anadolu yemek aşçılığı/lokanta tarihi, 17. yüzyılın ikinci yarısında sadece saray ve konaklarda değil, lonca teşkilatının kurulması ve çeşitli esnaf örgütleri marifetiyle yapılan halka açık aşevleri ve yeme-içme organizasyonları ile gerçekleştirilmesi ile başlar. Anadolu'da imarethane ve aşevleri halkın ihtiyacını [maddi bir çıkar gözetmeksizin] karşılamasına rağmen, özellikle büyük şehirlerde bunların dışında dışarıda yeme ihtiyacını

göstergesidir. Herhangi bir entelektüelden çok daha fazla takdir edilen kişidir iyi bir aşçı.” bkz. Ortaylı, 2006: 80; ayrıca bkz. Bingöl, 2005: 29-31.

${ }^{6}$ Burada, Türklerin yeme-içme alışkanlıklarının (tarımsal yapı ve konar-göçer kültürünün etkisi, başka toplumlardan etkilenme, sosyo-ekonomik düzeye göre farklılaşma, davranış kalıpları, yemeklerin bölgelere göre farklılıklaştırdığı ve toplu yemek yeme geleneği gibi faktörler) bu süreci etkilediği görülmektedir. bkz. Güler, 2010: 6; Osmanll-Türk yemek kültürü kitapları için ayrıca bkz. Kut, 2020; Güldemir, 2015. 
karşılama mekânları olarak lokanta organizasyonların kurulduğu izlenir (Ak, 2007: 19). Bu bağlamda günlük-ticari yaşamı kolaylaştırmak ve desteklemek üzere üretim/ekonomik değer alış-verişinin sarmaladığı çarşılarda lokanta esnafi/işletmeleri, kent hayatının ayrılmaz bir parçası ve esnafın evi olarak han, bedesten, arasta, çarşı ve pazar içinde konuşlanarak, şehir dokusunun ve ticaretin vazgeçilmez unsurları olmaktadır. (bkz. Mortan, Küçükerman, 2010: 107-139.)

Öte yandan Türk-Anadolu mutfak kültürü içinde yemek çeşitleri, yemek pişirme ve muhafaza teknikleri ile kendine has bir mutfak/yemek kültürü oluşturan Selçuklular döneminde kervanların izlediği güzergâhlarda yer alan kervansaraylar, bugünün TürkAnadolu lokanta işletmeciliği tarihi açısından değerlendirilebileceği söyleyebilir. (bkz. Merçil, 2000: 25-26) Selçuklu Sultanları ve devlet adamları tarafindan veya Ahilik kurumunun ödevlendirilmesine bağlı inşa edilen ve düzenli hizmetlerin [vakıflar tarafından] verilmesi ile sürekliliği sağlanan kervansaraylarda, hiçbir din, dil, ırk, cinsiyet vs. ayrımı gütmeksizin kervan ahalisinin konakladığı, ağırlandıkları ve dinlendikleri yerler ve her öğün çıkan yemekler ile güven yaratan kurumlar olarak izlenmektedir. (Ahilik için bkz. Şimşek, 2020) Hatta bu konuda ünlü Türk seyyahı Evliya Çelebi meşhur eseri Seyahatname'sinde [IV. Murat devri (1623-1640)], lokanta işletmeciliğinin ne kadar önemli ve yaygın bir sektör olduğu anlatısı delil gösterilebilir: ${ }^{7}$ Vezir çaşnigir ve aşçılar esnafi, zerdeciler esnafi, turşucular esnafi, sucukçular esnafi, dolmacılar esnafi, hardalcılar esnafi, salatacılar esnafi, hoşafçılar esnafı, şerbetçiler esnafi, salepçiler esnafi, helvacılar esnafı, akideciler esnafı, balıkçılar esnafı, yahniciler esnafı, kebapçılar esnafı gibi lokanta işletmeciliğinin uzman bölükleri olarak hizmet verildiği ifade edilir.

Özellikle 19. yüzyılda "Avrupaileşme” modası ile birlikte, lokanta işletmeciliği içeriğinin dönüşümü, "1840-1860 yılları arasında Cadde-i Keribar (İstiklal Caddesi) üzerinde açılan lokanta, kahvehane ve gazino işletme sayısında yadsınamaz artışa yol açtığı görülür. 1890-1920 yılları arasında "alafranga (Avrupaî)" diye tabir edilen yemekler genellikle otellerin lokanta işletmelerinde usta aşçılar tarafından yapılarak sunulduğu, bu yönde "Ayaspaşa' daki Park Otel, Pera'daki Tokatliyan ve Sümer Palas, Hotel de la France, Hotel D’Angleterre Fransız türü mutfakları ile bu döneme damgasını vurduğu ifade edilir (Gürsoy, 1995: 64).

Yine 19.yüzyılda Batı ile ilişkilere bağlı Avrupa'dan etkilenmeye başlayan Türk-Anadolu mutfak/yemek kültüründe etnik grupların etkisi ile eşzamanlı yaşanan değişim, Cumhuriyetin ilanı ile başkent Ankara'ya taşınır (Ak, 2007: 19). 1879 yılında modern tarzda ilk hizmet veren Konya Lezzet Lokanta işletmesi kurulur. Bunu 1888 yılında İstanbul'da, Kastamonu İnebolu'dan gelen ve Abdullah Efendi tarafindan Galata'da açılan, önce Viktorya, sonra Abdullah Efendi adı verilen lokanta işletmeleri izler. Bugün İstanbul Ağa Cami yanında Sakızağacı Caddesinde Abdullah Efendi lokanta işletmesi, OsmanlıTürk-Anadolu mutfağının modern tarzda sunulduğu nadir lokanta işletmelerinden biri olarak hâlâ faaliyet göstermektedir. (bkz. Bingöl,2005: 37-44)

\footnotetext{
${ }^{7}$ O dönemde geleneksel yemek aşçılığı esnafinın (ashâbu'l matâbıh) toplam dükkân sayısı 95, bu dükkânlarda çalışanların sayısı 500 civarında olduğu belirtilmektedir. Hatta bu durum kebapçı [kızartılmış et-söklençi] esnaflığını, geleneksel pirli mesleklerden biri olarak değerlendirilmesine dayanak oluşturur. Avf oğlu Abdurahman "Kebapçı Esnafi piri” olarak kabul edilmiştir. bkz. Bingöl, 2005: 38.
} 
(b) Geleneksel yemek aşçılığı olarak kebapçılık: Geleneksel yemek aşçılığı olarak kebapçılık, Ortadoğu kökenli bir kavram olduğu düşünülür ve Türk, Arap, İran ve Anadolu mutfak kültüründe yemek türü ve statülerinden birini oluşturur. (bkz. Şavkar, 2000: 65-67; Çetin, 2006: 111) Şavkar'a (2000) göre kebap, Farsça kökenli, İranlılara ve Araplara ilişkin, Ortadoğu'dan Türk ve Anadolu mutfak/yemek kültürlerince benimsenmiş bir kapsamı oluşturur. (bkz. Şavkar, 2000: 65; ayrıca bkz. Davidson, 2014: 442.) Doğrudan meşe kömüründe veya odun fırınında, etin pişirilmesini, közlenmesini veya kızartılmasını ifade eden kebap ${ }^{8}$, zamana ve etkileşime bağlı sözgelimi sebzelerin köz üzerinde doğrudansusuz pişirilmesi ya da testide veya tencerede pişirilen sözgelimi tas kebabı gibi sulu yemekler, köfteler, göveçler ve diğer yemek yapma biçimleri için de kullanıldığı görülür. (wikipedia, Türkiye'de 106 kebap adını yazmıştır. bkz. https://tr.wikipedia.org/wiki/Kebap)

$\mathrm{Bu}$ kapsamda kebap/çılık tarihi ve menşei konusunda muhtelif yaklaşımlar geliştirilebilir: (bkz. Gowlett, 2016: 1-12; Rowlett, 1999: 741; Standage, 2016; Civitello, 2019) Sözgelimi arkeolojik olarak yaklaşık 790 bin yıl önce insanların ateşi kontrol altına alması ile beraber kebapçılığın izleri sürülebilir ve ateşin yemek pişirmek için kullanılması ile açıklama kapasitesi tartış1labilir; antropolojik olarak insanın et pişirme biçimleri ve uygulamaları da buna bağlı değerlendirilebilir. ${ }^{9}$

Öte yandan kebap için İyonyalı (İzmirli-Smyrna) Homeros’un “İlyada” kitabında yakarış sonrası kesilen kurbanlar ve ziyafet yemeği için "ateşte et”in nasıl pişirildiği yani kebap anlatısı dikkat çeken bir değerlenmedir: (Homeros, 2008: 87-88)

\begin{abstract}
"Böyle dedi, verdiği sevgili kızını, o da aldı sevine sevine. Değerli kurbanları dizdiler sunağın çevresine, ellerini yudular, aldılar avuçlarına arpa taneleri, kaldırdı Khryses ellerini, yüksek sesle yakardı: “Ey Khryse'yi, kutsal Killa’yı koruyan, gümüş yaylı, Tenedos'un güçlü kralı, dinle beni! Yakarmalarımı nasıl dinlediysen bundan önce, Akhaların ordusuna yumruğunu nasıl indirdiysen, beni sayıp, şimdi de tezelden yerine getir şu dileğimi: Uzaklaştır amansız salgını Danaolardan." Böyle yakardı, Phoibos Apollon da dinledi onu. Hepsi yakardılar, arpa taneleri serptiler yere, başlarını arkaya kaldırıp kurbanları kestiler, derilerini yüzdüler, butlarını ayırdılar, yağlı gömlekle sardılar butları iki kat, sonra etler kodular üstüne çiğ çiğ. Odunların üstünde kızarttı ihtiyar onları. Şarap döktü üzerlerine, ateş gibi, pırıl pırıl. Beş dişli çatal tutuyordu yanında delikanlılar. Butlar kızartıldı, ciğerler, yürekler yenildi, kalan etler parçalandı, şişlere geçirildi, kızartıldı iyiden iyi, çekildi hepsi ateşten. İşler bitti, şölen hazır oldu, yenildi içildi. Şölende eş pay aldı her insan, yakınmadı bir tek kişi. Yenilip içilince doyasıya, delikanlılar şarapla doldurdular ağaç kadehleri (sağrakları), taslarla dağıttılar, tanrılara sunmak için, korolarla yatıştırdılar tanrıyı, gün boyunca. Koruyucu tanrıya şükürler edip güzel bir övgü söyledi Akha delikanlıları."
\end{abstract}

10. yüzyılda İbn Sayyar al-Warraq'1n günümüze intikal eden tek kitabı, Bağdat el yazması (çeviri) yemek kitabı "Kitab al-tabikh"te, ateş üzerinde/1zgarada yapılan ve tava içinde kızartılan etlere dair kebaplar tarif edilir. Ayrıca şişe geçirilmiş küçük et parçalarının, Yakın ve Orta Doğu yemek kültür tarihinde kayıtlarda izlenebilir. (Irak yemek kültürü ve tarihi araştırmacısı,Orta Doğu mutfă̆ı uzmanı Nasrallah'ın kitabı için bkz. Nasrallah, 2007: 40) Ancak kebap benzeri yemeklerin tüm kültürlerde, avcı ve toplayıcı grupların etin

\footnotetext{
${ }^{8}$ Bu konuda Çağdaş Etimolojik Sözlük Nişanyan'a göre kelime kökeni “kızartmak/yakmak” anlamına gelen eski Akadca "kabābu" ve Aramice "kbabā” kelimelerinden gelmiştir. Öte yandan Orel ve Olga (1995) 1986 yılından beri yapılanan karşılaştırmalı "Hamito-Semitik Etimolojik Sözlük”te, soyu tükenmiş Proto-Hamito-Semitik (Proto-Afro-Asya) dili kelime dağarcığına ilişkin kebap, kab-yakmak veya kızartmak şeklinde tarih öncesi Proto-Afroasyatik bir dilden gelmiş olabileceği değerlendirilir. bkz. https://www.nisanyansozluk.com/?k=kebap; ayrlca bkz. Orel, Stolbova, $1995: 307$. ${ }^{9}$ Hatta daha ileriye giderek, Harvard Üniversitesi’nden antropolog ve primatolog Richard Wrangham ve diğerleri (1999) "Current Anthropology” çalışmasında, insanın pişirme yeteneğinin fizyolojik evriminde özellikle büyük beyinlerin, daha küçük dişlerin, uzuv oranlarının ve hatta erkek-dişi bağlamı evrimine yol açtığı yorumlanır. bkz. Wrangham, vd. 1999: 567-594; ayrica bkz. Wrangham, 2009; Pennisi, 1999: 2004-2005.
} 
ateşle buluşmasına bağlı geniş bir tarihsel coğrafyada [Asya'dan Afrika'ya, Avrupa'dan Amerika'ya, Afganistan'dan Moğalistan'a, Pakistan ve Hindistan'tan Bosna-Hersek ve Arnavutluk'a, Azerbeycan'dan Suriye, Ürdün, Filistin'e vs.] ele almak ve ilk dönem yemek pişirme uygulaması olarak söz etmek mümkündür ve/dahi özelde Türkiye, Orta Doğu ve ilişkili coğrafyaların yemek kültürü ve aşçılık mesleği içinde severek değerlendirilen ve yaygın yiyime sahip olduğu düşünülebilir. (https://tr.qaz.wiki/wiki/Kebab)

\section{Kebapçı Esnafi/Lokanta İşletmelerinde Sürdürülebilir Rekabet ve Temel Yetenekler}

Günümüz rekabet ortamı kebapçı esnafi/lokanta işletmelerinin uzun vadeli ayrıntılı tahminler yapmasını -tüm işletmeler için olduğu gibi- zorladığı söylenebilir. Daha açık olarak yoğun sektörel çevre, yeni-alternatif rakiplerin durumu ile yaratılan belirsizlik ve karmaşa, kebapçı esnafi/lokanta işletmelerinin rekabette daha etkili stratejiler geliştirmesini gerektirmektedir. $\mathrm{Bu}$ sadece rekabette dezavantajları ortadan kaldırmak ve ayakta kalmak değil, rekabeti sürdürme ve avantaj yaratma konusunda farklı yollarını aramak ve bulmak olarak düşünülür. Çünkü her işletme aynı parametreler ile rekabet ediyorsa, rekabetçi avantaj yaratabilmek zor gözükmektedir. Diğer bir deyişle kebapçı esnafi/lokanta işletmelerinin temel yeteneklerini sürdürülebilir rekabet (rekabetçi avantaj ve üstünlük yaratma) için geliştirmesi gerekmektedir. ( $b k z$. Gibson, 1997: 45-54)

Genel itibariyle işletmelerin geleceğe dönük geliştireceği ve gerçekleştireceği faaliyetler, pazar konumu oluşturma ve temel yetenekleri kullanma, rakiplerine nazaran taklit edilmeyen ve sürdürülebilir rekabetçi avantaj sağlamaya yönelik ele alınır. Sürdürülebilir rekabetçi avantaj ise kaynaklar, yetenekler ve temel yetenekler üzerine kuruludur. (bkz. Çizim 1) Bunun için başta değişimi fark eden, teknoloji avantajlarından etkili biçimde yararlanan, yenilik için gerekeni yapan dolayısıyla her şeyi sürekli düşünen ve gözden geçiren bir vizyon öncelenmesi gerekir. Bu noktada sürdürülebilir rekabetçi avantaj1 üstünlüğe dönüştürmeye ilişkin stratejinin yalın anlamda işlevsel etkinlikten çok, benzersizlik açısından düşünme ve temel yetenekleri üstünlüğe dönük sürgitlenmesi önemsenir. (bkz. Papatya, 2007: 38)

Çizim 1: Sürdürülebilir Rekabet için Analiz Bileşenleri

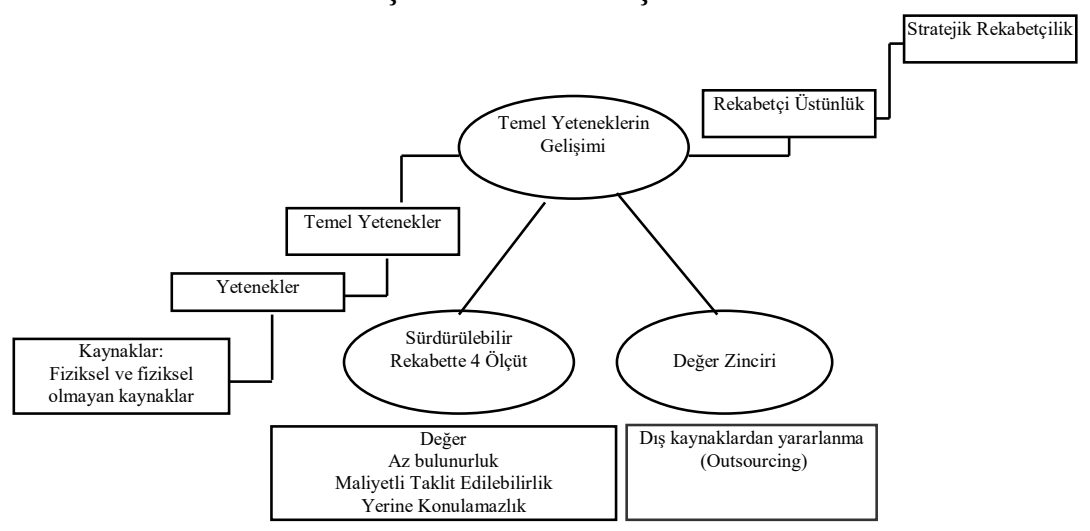

Kaynak: Hitt, Ireland, Hoskisson, 1999: 89.

Temel yetenekler yazında farklı araştırmacılar tarafindan çeşitli karşılıklar ile kullanılmış, "çekirdek/öz yetenekler, temel yetkinlikler, ayırt edici yetkinlikler, organizasyonel yetenekler, stratejik yetenekler, dinamik yetenekler" biçiminde kavramsallar ile 
tanımlanmış, kavramlar arasında zorlamalı farklar verilmeye çalışılmıştır: (bkz. Kaplan, 2021) Sözgelimi Barney (Barney, 1997) çekirdek yetenekler, Prahalad ve Hamel (Prahalad, Hamel, 1990: 79-91) çekirdek yetkinlik olarak işletmelerin sürdürülebilir rekabette avantaj sağlayan beceri ve teknoloji demeti olarak varlık ve süreçleri içerecek şekilde ele almıştır. $\mathrm{Bu}$ bağlamda temel yetenekler tanımlanmış ve sürdürülebilir rekabetçi üstünlük ve müşteri değeri sağlamak için beceriler, varlıklar, süreçler, normlar, teknolojiler vs. olarak ifade edilmiştir. Böylece pek çok kez vurgulanan anlaşılmaz yönler giderilmesine çalışılmış ve/dahası sürdürülebilir rekabet avantajı için (Barney, 1997; Daft, 1983) işletmenin varlıkları, yetenekleri, yetkinlikleri, süreçleri, öz-nitelikleri, normları, bilgileri vs. kontrol edilen, düzenlenen, verimlilik ve etkenliği artıran stratejiler, taktikler, işlevler, faaliyetler ve işlemler olarak düşünme, ortak tanım yapma ve kuramsal yaklaşım geliştirme yönelimi oluşturma düşüncesi hedeflenmiştir. (bu makale için temel yetenekler yazınında ana kuramsal yaklaşımlar Tablo 1'de izlenebilir):

Tablo 1: Yazında Temel Yetenek Tanımlarına Dair Başlıca Kuramsal Yaklaşımlar

\begin{tabular}{|c|c|c|}
\hline Odak kavram & Tanım & Kaynak \\
\hline Yönetici görevi & $\begin{array}{l}\text { İşletmenin ihtiyaç duyduğu temel yetenekleri ve kaynakları } \\
\text { belirleme bir yönetici görevi. }\end{array}$ & $\begin{array}{l}\text { bkz. Grant, 1991; Schulze, 1993; Klein, Hiscocks, 1994; } \\
\text { Collis 1994; Tampoe, } 1994\end{array}$ \\
\hline Strateji plan & $\begin{array}{l}\text { Yeteneklerin geliştirilmesi için etkili (özellikle finanssal niteliğin } \\
\text { öncelendiği) stratejik plan yapma. }\end{array}$ & $\begin{array}{l}\text { bkz. Naugle, Davies, 1987; Reed, Defillipi, 1990; } \\
\text { Prahalad, Hamel, 1990; Stalk vd. 1992; Collis, } \\
\text { Montgomery, } 1995\end{array}$ \\
\hline İzleme sistemi & $\begin{array}{l}\text { Yetenekler veya belirli kişiler ile ilişkili kişiler için bir izleme } \\
\text { sistemi. }\end{array}$ & bkz. Naugle ve Davies, 1987 \\
\hline $\begin{array}{l}\text { Yönetim } \\
\text { organizasyonu }\end{array}$ & Yönetim kaynaklarını toplama, düzenleme ve dağıtma. & bkz. Doz, Prahalad, 1988; Schulze, 1993 \\
\hline Yönetim önceliği & $\begin{array}{l}\text { Özellikle finansal etki açısından organizasyonda öncelikli } \\
\text { yetenekleri vurgulama. }\end{array}$ & bkz. Simmons, 1990; Hall, 1993 \\
\hline $\begin{array}{l}\text { Yönetim } \\
\text { teknolojisi }\end{array}$ & $\begin{array}{l}\text { Finansal getiriyi (örgütsel performansı) değerlendirmek için } \\
\text { rakiplerinden farklılaşan bir sistem oluşturma. Sistemde temel } \\
\text { yetenekler kaynakların bir araya getirilmesi, geliştirilmesi ve } \\
\text { avantaj yaratmaya yönelik dönüştürülmesini sağlar: Hayatta kalma } \\
\text { stratejileri, muhasebe önlemleri, paydaş yaklaşııları, değer zinciri } \\
\text { yönetimi gibi kapsamlar öncelenir. Ancak en popüler muhasebe } \\
\text { önlemleri, işletmenin performansını izlemek konusunda yardımcı } \\
\text { olur. Buna yönelik farklı ölçümler izlenebilir. }\end{array}$ & $\begin{array}{l}\text { bkz. Lado vd.,1992; Hall, 1992; Barney (1997); ayrıca } \\
b k z \text {. Toplam gelirlerin, toplam varlıklara oranı (Snow ve } \\
\text { Hrebiniak, 1980); piyasa getirileri (Hitt, Irlanda, 1986); } \\
\text { piyasa yatırım getirisi (Haskell, 1989); birkaç yıllık } \\
\text { dönemde satışlarda/çalışanlarda artış (Hall, 1992); Cho } \\
\text { (1996) ve Ventrice (1983) nakit önlemlerin finansal } \\
\text { yatırımlar için tek gerçek önlem olduğunu önerir. }\end{array}$ \\
\hline
\end{tabular}

Kaynak: Tablo Chabert, 1998'e bağlı düzenlemiştir.

Temel yetenekler bir işletmeyi diğerlerinden ayıran özelliktir. Temel yeteneklerin fark edilmesi ve tanımlanması geliştirilmesinin ilk şartıdır. Ancak her işletme için temel yetenekler farklılık gösterir. İşletme kültürü ve bağlamsallıklar içinde farklı şekillerde kendini gösterir. Bu nedenle her işletmenin temel yeteneklerini ayrı ayrı ele almak ve değerlendirmek gerekir.

Yazında temel yetenekler stratejik çalışmalar ile eşdeğerde ele alınır ve sürdürülebilir rekabette başat kapsamı oluşturur. Stratejik yetenekler olarak strateji ile eşleştirilir. Ancak her durumda temel yeteneklerinin müşteri faydası/değeri yaratması umulur. Gerçekleştirilen üretim ve ortaya konan ürünler/hizmetler buna yönelik ele alınır. Çünkü müşteri değerli gördügünü talep eder. Aksi halde rakip tercihler, işletmenin mevcut temel yeteneklerinin bozulmasına yol açabilir. Bu nedenle rekabette, bir bakıma rakibin temel yeteneklerini bozma stratejisi hedeflenir. Rakipler bu amaçla izlenir. Temel yetenekleri üstelemeyen işletmeler [hatta işletme finansal yeterliliğe sahip olsa da] rekabet avantajını sürdürülmez. Ayrıca sürdürülebilir rekabetçi üstünlüğünün entemel özelliği, değişs-tokuş edilemez, yeri doldurulmaz ve kolaylikla toplanamaz avantajlara ve/veya kaynaklarla olan 
bağlantısıdır. Bu noktada temel yetenekler etki ajanı (katalizör) rolü üstlenmektedir. (bkz. Çizim 2)

Çizim 2: Temel Yeteneklerin Etki Ajan (Katalizör) Rolü

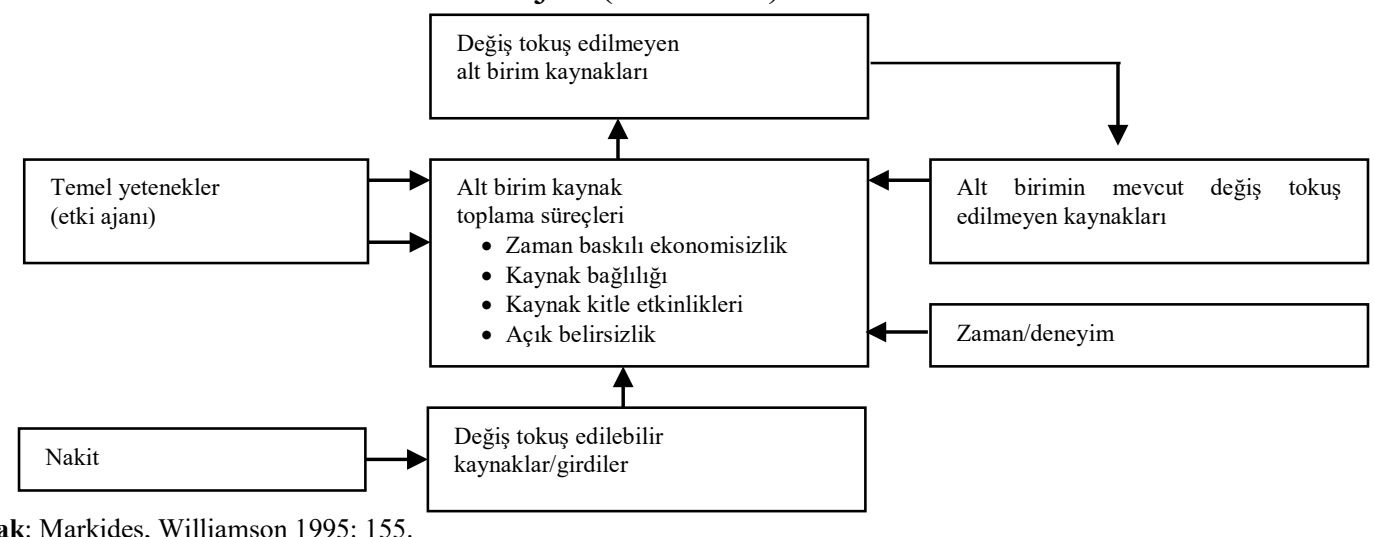

Kaynak: Markides, Williamson 1995: 155.

Temel yeteneklerin yenilenmesi, iyileştirilmesi ve geliştirilmesi veya her yeteneğin zamanla rekabetçi değerinin bozulması karşısında vazgeçilmez bir süreç olarak izlenir. Aslında bu yeniliği teşvik edici de bir koşuldur. Kebapçı esnafi/lokanta işletmeleri bağlamında çok azının yenilik yetenekleri (innovation abilities) koşulunu sağladığı ve gerçekleştirdiği söylenebilir ve/dahi yeni geliştirilen yetenek performansını sürdürülebilirlik açısından değerlemek de çok kolay olmaz. Hatta bu yönlü çabalar, genelsel kebapçılık ve işin doğası açısından hayata geçirilmesi direnç ile karşılanabilir. $\mathrm{Bu}$ nedenle yenilik yenilenme [bütünleşik] yeteneklerinin (innovation regeneration [integrated] abilities) bir yapılandırılması olarak karşımıza çıkar. Yani kebapçı esnafi/lokanta işletmelerinin yeteneklerini yenilemesi, teknik becerilerinden pişirme becerilerine, yönetsel yeteneklerinden sunum yeteneklerine kadar geniş yelpazede değerlendirilmesine bağlı zuhur eder. Ancak önce rekabette firsatları keşfetmek ve değerlendirmek, sonra bütünleşik yeteneklerin oluşumunu, yenilenmesini, iyileştirilmesini ve geliştirilmesini sağlamak gerekmektedir.

\section{Isparta İli Kebapçı Esnafı/Lokanta İşletmelerinde Bir Araştırma}

\section{Araştırmanın Tanımı ve Modeli}

Araştırma, Chabert yaptığı akademik çalışma kapsamında şu şekilde tanımlanmış ve modellenmiştir: (bkz. Chabert,1998)

Araştırma Amacı, Sınırlılıkları ve Kapsamı: Araştırmanın amacı Türk-Anadolu yemek aşçılığında önemli bir yere sahip kebapçı esnafi/lokanta işletmelerinin rekabet anlayışlarını araştırma ve bu anlayışa yön veren temel yetenekleri değerlendirme konusunda bilgilerin derinlemesine incelenmesi ve ayrıştırılmasıdır. Böylece sürdürülebilir rekabette tutarlılık ölçütleri ortaya koymak hedeflenmektedir. Bir bakıma geçmişten günümüze kalan kebapçı esnafi/lokanta işletmelerine dönük rekabet gerçeklerini ortaya çıkarmak ve yeni kebapçı lokanta işletmelerinin sürdürülebilirlik rekabette gerekli olan temel yeteneklerin ne olması gerektiği ve dönüştürme konusunda ipuçları sağlamak umulmaktadır.

Bu bağlamda araştırma Türkiye'de Oğuz Erkara tarafindan kataloglanmış ve bugüne kadar itibarî değerini muhafaza etmiş "100 Tarihi Lokanta” adlı eserinde, Isparta'da kesintisiz faaliyet 
gösteren ve "kadim kebapçılar" olarak nitelenen, kuruluş tarihleri en az bir asra dayanan, atadan işletmeci Kebapçı Hacıbenlioğlu, Kebapçı Kadir ve Kebapçı Ferah olarak üç kebapçı esnafi/lokanta işletmesi üzerinde yapılmıştır. ${ }^{10}$

Ancak daha önce araştırma için kebapçı esnafi/lokanta işletmelerine ilişkin yapılmasına yönelik güçlendirici dayanaklar aranmış, Isparta kebapçı esnafi/lokanta işletmelerine dair dokümanlar toplanmış, gözlemler/görüşmeler yapılmış ve alan notları çıkarılmıştır. İlin eski gazeteleri ve dergileri taranmış, ileri gelenler ve kanaat sahibi kişiler ile görüşülmüş ve bu istikamette 1800 'lü yılların ortalarından bu yana faaliyet gösteren üç lokanta esnafi/işletme üzerinde araştırma yapılmasına karar verilmiş ve araştırma sınırlandırılmıştır.

Buna göre araştırma uygulama ve yürütme modeli düzenlenmiştir: (bkz. Çizim 3)

Çizim 3: Araştırma Uygulama ve Yürütme Modeli ve Argümanları

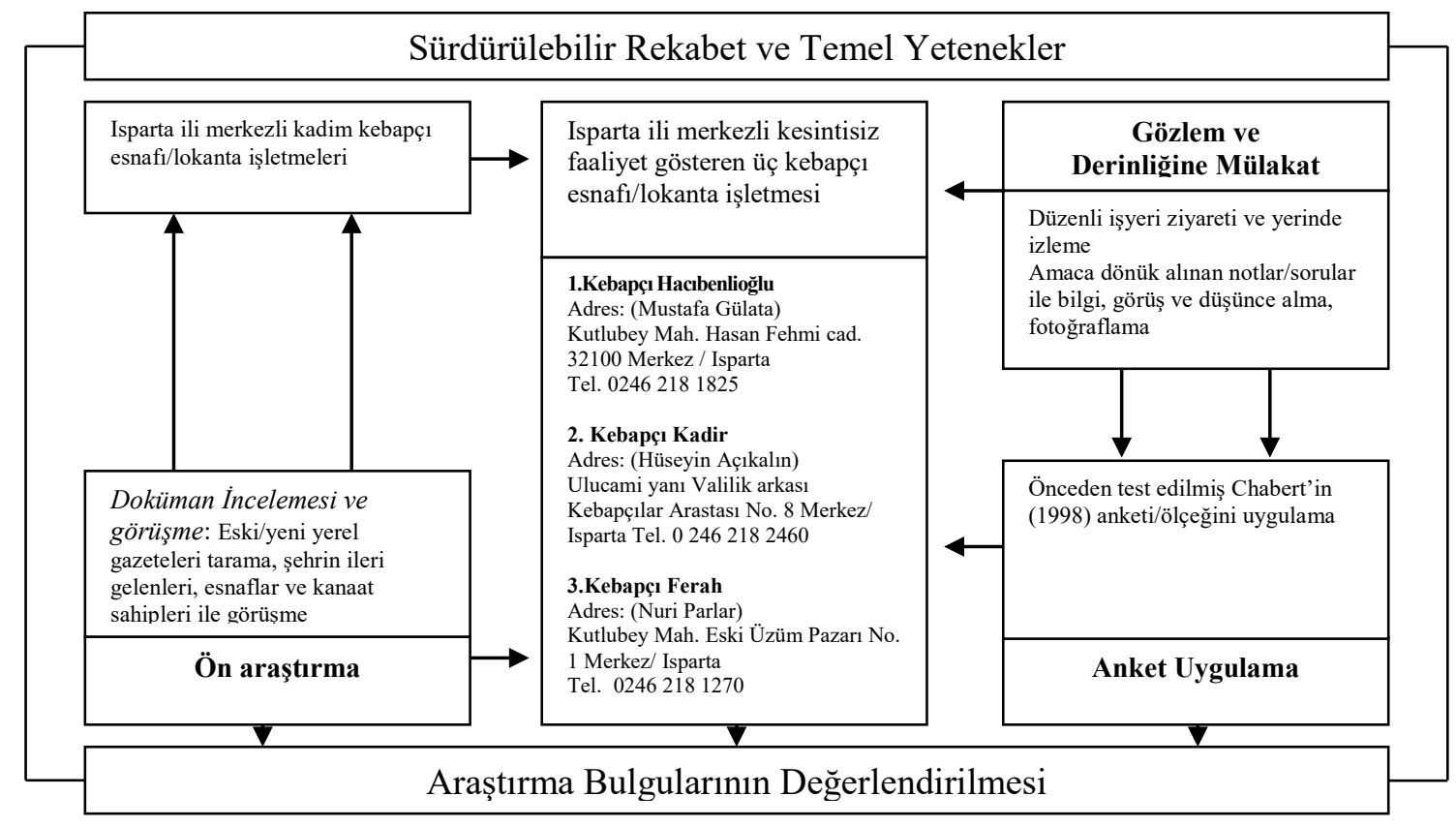

Araştırma Yöntemi ve Örneklem: Araştırmada sürdürülebilir rekabette temel yeteneklerin belirlenmesine yönelik nitel-nicel yöntemlerin bir arada kullanıldığı karma (mix) yöntem izlenmiştir. ${ }^{11}$

Nitel yöntem Kebapçı esnafi/lokanta işletmelerin mevcut kültür içinden bakış, betimleme ve yorumlama açısından tercih edilmiştir. Nicel yöntem anket tekniği uygulaması şeklinde yapılmıştır. Bu nedenle araştırma, gözlem, görüşme ve derinliğine mülakat tekniklerini içeren etnografik temelli nitel ve önceden güvenilirliği ve geçerliliği test edilen ve

\footnotetext{
${ }^{10}$ Erkara kitabında [Madrid'te ilk defa kurulmuş olan lokanta işletmesi tarihini (1833) ölçüt alarak] yaptığ sıralamada Isparta'dan üç kebapçı esnafi/lokanta işletmesi, Kebapçı Hacıbenlioğlu'nu 1. sırada, Kebapçı Kadir'i 2. sırada, Kebapçı Ferah da 51. surada listelemiştir. bkz. Erkara, 2010:

${ }^{11}$ Karma yöntem yazında bir sektöre/işletmeye ilişkin bilgilerin sadece anketler ile nicel teknikler kullanılarak ölçme ve tanımlama çabasının yetersiz kalmasına veya bilgilerin tamamlanmasına dair ele alınır. Ancak nitel araştırmaların da bilimsel araştırmalarda kullanılması sorunlu görülür. Yine de nitel yöntemin ve araştırmaların bilgibiçimsel (epistomolojik) temelleri söz konusudur. bkz. Brannen, 2005: 173-184; Greene, 2005: 207-211; Creswell, 2013; ayrlca bkz. Kvale, 1994: 147-173.
} 
uygulanan bir anket tekniği ile nicel iki boyutlu görgül (durum araştırması) ve karşılaştırılmalı analiz biçimli ele alınmıştır.

Araştırma kapsamına dâhil edilen kebabçı esnafi/lokanta işletmeleri açıkça tanımlanmış temel yeteneklerin farkında ve sürdürme konusu ön-kabulüne bağlı, bir asır sürekli mevcut yeteneklerini geliştirme, uygulama, dağıtım için kaynak ayırdığ [sisteme sahip] ve temel yetenekleri koruduğu öndeyisi izlenmiştir; temel yeteneklere bağlı kaynak tahsisi, iletişim ve finansal performans gibi temalara dair bulgulama hedeflenmiştir. Buna bağlı temel yetenekleri destekleyen kebapçı esnafi/lokanta işletmeleri için yönetici, hizmet sunumu ve aşçı beceri düzeybilgileri (kategoriler) oluşturulmuştur. Bu düzeybilgiler temel yeteneklerin geliştirilmesine ve daha hızlı sonuç alınmasına dönük değerlendirilmiştir. $\mathrm{Bu}$ değerlendirmeyi destekleyen varlıklar, yetenekler, beceriler, süreçler, normlar, teknolojiler vs. vurgulanmıştır. Vurguların testi için yazın bilgileri ve akademik görüş desteği sağlanmıştır.

Örnekleme seçiminde Teddlie ve Yu'nun (Teddlie, Yu, 2007: 77-100) sınıflandırdı̆̆ kolay ulaşılabilir, hem de gönüllü katılmaya dönük "uygunluk örneklemi” kullanılmıştır. Ayrıca araştırmada Creswell'in (Creswell, 2003) "eşzamanlı dönüşümsel tasarım"1 esas alınmış; yani nicel ve nitel veriler aynı zamanda toplanmış, ve/fakat nitel ve nicel verilerin ayrı ayrı analizi yapılmıştır. Buna göre seçilen üç kebapçı esnafi/lokanta işletmesinde araştırma gerçekleştirilmiştir. Araştırma sonunda elde edilen nitel ve nicel verilerin birbirini desteklenmesine ve doğrulamasına yönelik birleştirme ve yorumlama yapılmıştır.

Araştırmanın Yürütülmesi: Araştırma birbirine bağlı şu üç adım şeklinde yürütülmüştür: ${ }^{12}$

(a) Hareket soruları: Başlangıçta, yapılan araştırma odağına ve tasarıma bağlı Yin (Yin, 1994) tarafından önerilen soru ifadelerinden hareket edilmiştir. (bkz. Tablo 2)

Tablo 2: Araştırma için Başlangıç Öneri Soru İfadeleri

\begin{tabular}{|l|l|}
\hline Soru Niteliği & Soru İfadesi \\
\hline Strateji-temel yetenekler bağlantısı & $\begin{array}{l}\text { Yöneticiler, amaçladıkları stratejiyi gerçekleştirmek için gerekli olan temel yetenekleri } \\
\text { tam olarak belirleyebiliyor mu? }\end{array}$ \\
\hline $\begin{array}{l}\text { Temel yetenekler-diğer kaynaklar } \\
\text { bağlantısı }\end{array}$ & $\begin{array}{l}\text { Yöneticiler temel yeteneklere bağlı uygulamaları gerçekleştirecek süreçleri, becerileri, } \\
\text { varlıkları ve teknolojileri tam olarak belirleyebiliyor mu? }\end{array}$ \\
\hline Temel yetenekler-uygulama bağlantısı & $\begin{array}{l}\text { Genel birim yöneticileri, temel yeteneklere bağlı uygulamaları gerçekleştirecek } \\
\text { süreçlerin, becerilerin, varlıkların ve teknolojilerin ne olduğunu anlıyor mu? }\end{array}$ \\
\hline Temel yetenekler-yönetici algı bağlantıs1 & Birim genel müdürleri işletmenin temel yeteneklerinin ne olduğunu açıça anlıyor mu? \\
\hline $\begin{array}{l}\text { Temel yetenek-yönetici- kaynak } \\
\text { bağlantısı }\end{array}$ & $\begin{array}{l}\text { Yöneticiler, yeteneklerin ana kaynakları geliştirme ve sürdürme konusunda yeterli kaynak } \\
\text { ayırıyor mu? }\end{array}$ \\
\hline $\begin{array}{l}\text { Yönetici-temel yetenek-iletişim } \\
\text { bağlantısı }\end{array}$ & Yöneticiler, işletmenin yeteneklerini genel birim müdürlerine iletiyor mu? \\
\hline $\begin{array}{l}\text { Yönetici-temel yetenekler- ekonomik } \\
\text { etki bağlantısı }\end{array}$ & $\begin{array}{l}\text { Yöneticilerin temel yeteneklerinin ekonomik etkisini değerlendirme yolları bulunuyor } \\
\text { mu? }\end{array}$ \\
\hline $\begin{array}{l}\text { Yönetici-temel yetenekler-finansal } \\
\text { performans bağlantısı }\end{array}$ & $\begin{array}{l}\text { Yöneticiler ile birim yöneticileri temel yeteneklere bağlı gerçekleşen finansal performans } \\
\text { yaratma gücü bulunuyor mu? }\end{array}$ \\
\hline $\begin{array}{l}\text { Yönetici-temel yetenekler-diğer kaynak } \\
\text { ve teknoloji bağlantısı }\end{array}$ & $\begin{array}{l}\text { Yöneticiler ile birim yöneticiler, gerekli süreçler, beceriler, varlıklar ve teknolojiler } \\
\text { önemli ölçüde etkiliyor mu? }\end{array}$ \\
\hline $\begin{array}{l}\text { Strateji-Yönetici-temel yetenekler- } \\
\text { kaynaklar ve işletme performansı } \\
\text { bağlantısı }\end{array}$ & $\begin{array}{l}\text { Temel yetenekler daha yüksek bir seviyede performansa yönelik açıç̧a tanımlanmış } \\
\text { kaynak tahsisi kanallarını işletiyor mu? }\end{array}$ \\
\hline
\end{tabular}

Kaynak: ayrica bkz. Chabert, 1998: 59-60.

\footnotetext{
${ }^{12} \mathrm{Bu}$ bölüm düzeni ve/veya düzenlemesi, temel olarak Chabert (1998) bilgilerine bağlı yapılmıştır.
} 
Sürdürülebilir Rekabette Temel Yetenekler: Isparta Kebapçı Esnafi/Lokanta İşletmelerinde Araştırma

İlgili soru ifadeleri ile sürdürülebilir rekabette temel yeteneklerin belirlenmesine ve açıklamasına yönelik bir kapasite değerlendirilmiştir.

(b) Görüşme notları: İkinci olarak, sözel tarihleme durum çalışması ve veri alanı için, daha çok "nasıl” veya "neden" soruları gözetilmiştir. Buna yönelik "çokyönlü, çeşitli kanıtlar, belgeler, eserler, röportajlar ve gözlemler (Yin, 1994: 8) izlenmiştir. Tek tek toplanan ve belleğe dayalı sözlü anlatımlı işletme verileri toplanarak, genel olarak Isparta Kebabçılığ tanımlanmıştır ve/böylece kebapçı esnafi/lokanta işletmelerinin temel yetenekleri nedensel bağlantıları keşfedilmiş ve makro açıdan açıklama potansiyeli araştırılmıştır. Eşzamanlı olarak nicel araştırma kapsamında sorulacak soruların (Yin, 1994: 20) [yapısal, iç ve dış] geçerlilikleri ve güvenilirliği yapılmıştır. (Campbell, vd., 1982; Yin, 1994: 33)

(c) Nitel ve nicel araştırma: Üçüncü olarak araştırmada Miles ve Huberman (Miles, Huberman, 1994)'in eşzamanlı üç faaliyet akışına bağlı yazılı, görsel malzemeler, bilgiler ve belgeler görüşmeler yoluyla toplanmış ve kullanılmıştır. Bu yönelim geçerlilik oluşturmaya yardımcı olmuştur. Açıklayıcı çalışmalar için iç geçerlilik için nedensel ilişkiler kurulmuş; dış geçerlilik (sözgelimi araştırma bulgularının genelleştirilebileceği alan oluşturma durumu) endişelerinin giderilmesine yönelik desteklenmiştir. Ancak güvenilirlik, başkalarının araştırmayı tekrar etme ve aynı sonuçları elde etme becerisiyle ilgili olduğu göz ardı edilmemiş, bunun için kullanılan prosedürler belgelenerek gerçekleştirilmiştir. Böylece sözel tarihleme konusunda bir yönelim oluşturulmuş, ve/fakat her işletmeyi ayrı ayrı ele almak ve çoklu vak'a çalışmaları yapmanın da mümkünlüğü izlenmiştir. Ancak bu yönde çalışma, odak konu ve amaçlılık kapsamında tercih edilmiş ve bunun yerine sürdürülebilir rekabette temel yeteneklere odaklaşmak hedeflenmiştir. Ayrıca çoklu vak'a yazma düşüncesinin bir şeklide yapılabilirliği korunmuştur. Nicel araştırmada anket aracılığıyla verilerin toplanmış, ankette Chabert'in (1998) anketi/ölçeği kullanılmış, geçerlilik ve güvenirliliği test edilmiştir.

Araştırma Veri Toplama Süreci: Araştırmanın başlangıcından itibaren temel yeteneklerin geliştirilmesi konusunda kaynak tahsisi ve finansal performans bilgilerinin katmanlaşması ve bunların incelenmesi zaman almış ve/hatta bu makale yazımına kadar katmanlaşmaya devam etmiştir. Ancak araştırmanın motivasyonu açısından başlangıç ile bitiş arasındaki süre kıvamın bozulmaması için 2021 Ocak ayı tarihi itibariyle tamamlanmıştır.

Öte yandan nicel uygulama için kebapçı esnafi/lokanta işletme çalışanların anketi doldurma ve temel yetenekler hakkında açıklama yapma önemli bir zaman almıştır. Çünkü soru/kavam algıları farklı olmaktadır. Öte yandan her işletmede daha alt yönetici/çalışanlar için, ayrı ayrı süreçler şekilde değerlendirilmiştir. Sıklıkla yapılan çapraz kontroller ve etnografik gözlemler ile veriler çakıştırılmıştır.

Ayrıca nitel araştırma için temel araştırma konusu ötesinde verilerin oluşturulması zorluk yaratmıştır. Hangi düzeyde veri olup olmadığı tartışılmış, özgü/l olanlar incelenmiştir. Etnografik teknikler bu yönde büyük katkı sağlamıştır. (bu yönde bkz. Geertz, 1973) Özellikle temel yeteneklerin tanımlamasına yönelik iyileştirmek için odak grup çalışmalar gerçekleştirilmiştir. Bireysel görüşmeler ve yeniden uygulanan (boylamsal) anketler ile veri 
kontrolleri sağlanmıştır. Böylece yöneticilerin algıları, işletme temel yetenek tanımlamaları, ortam ve durum koşulları daha kontrol edilebilir düzeye getirilmiştir. Bu bağlam yapılan konuşmalar, erişilen belgeler, elde edilen veriler ve yapılan düzenlemeler ile desteklenmiştir. Ayrıca araştırma sürecinde yüksek motivasyonu sağlamak ve bilimsel yönü iyileştirmek için çalışılmıştır.

$\mathrm{Bu}$ arada toplanan veriler birden fazla düzeybilgi olarak ayrıştırılmışıtır: Temel yetenekler, kaynak tahsisi, iletişim süreçleri ve finansal performans düzeybilgileri tanımlanmış ve temel yetenekler için nirengi belirlenmiştir. Geçmiş ve güncel veriler ve performans incelenmiş, finansal durum bilgilerin paylaşılmasından hoşnutsuzluk yaratmamak için azami özen gösterilse de, görgül araştırmanın tipik sorunları yaşanmıştır. Ancak tutarsız verilerin ortalaması alınarak, bilgi boşlukları kapatılmaya çalışılmıştır. Bu çalışma işletme performansını ortaya koyma konusunda sorun yaratmamıştır. Temel yetenekleri tanımlanan işletmelerde performans veya finansal durum eşleşmiştir.

Veri toplama süreci iki aşamalı geliştirilmiştir:

(a) Birinci aşama, içten (emic) bakış açısı bağlamında, Isparta kebapçı esnafi/lokanta işletmeleri yöneticileri/çalışanları ile etnografik teknikler yardımıyla nitel araştırma uygulanmıştır. 2017 y1lından itibaren katılımlı gözlem, yarı yapılandırılmış görüşmeler, kilit aktör ve odak görüşmeler ile bulguların çapraz sağlamaları yapılmış, verilerin bilgi haline dönüşmesi ve belgelenmesi için uzun süre ve çaba harcanmıştır. Isparta kebapçı esnafi/lokanta işletmeleri yöneticileri/ çalışanları ile mevcut işyerinde ve dışında toplam 17 biçimsel görüşme gerçekleşmiş, veriler değerlendirilmiştir. Genelde iş yoğunluğu nedeniyle işyeri görüşmelerinden ziyade, işyeri dışında görüşmelerin yapılması daha yararlı olmuştur.

Görüşme ve soruşturmalar, etik kurallara uygun, dinamik soru biçimleri ya da konunun akışına göre hazırlanan sorulara eklenen sorular ile yürütülmüştür. Bu süreçte ne tür etkileşimin gerçekleştirilmesi gerektiğine dair kararlar gözden geçirilmiştir. Gözlemci etkisini en aza indirmek için, araştırma amacı açıkça ortaya konmuş, görüşmelerde tepkisel olmaktan ve yorum yapmaktan uzak durularak sadece notlar alınmıştır. Araştırmanın uzun süreli olması, doğal olarak güven ve "arkadaşlık boyutlu" ilişkilerin gelişimi endişesi yaratmış, ve/fakat mümkün mertebe görüşmelerde araştırma yapılan konu kapsamının korunması sürecin işleyişini kolaylaştırmıştır. Böylece ortaya çıkabilecek bilimsel nitelikte sorulara cevaplar, kanıtlar ve belgeler sağlanmaya çalışılmıştır. Tüm görüşmeler ve notlar "müsaadeli gizlilik" içinde alınmıştır. Yılgınlık, bıkkınlık ve güven kaybı yaşamamak için görüşmeler ve konuşmalar hızlı notlanmıştır.

Verilerin gözlem, görüşme, alan notları, doküman tarama gibi birden fazla veri toplama yolu ile sağlanması muhtemel veri değerleme sürecinde çapraz kontrolü yapılmış, veri ve notlar arasındaki uyumsuzluklar yeniden sorgulanmış ve iç-dış geçerliği oluşturulmuştur. İç gerçeklikte yeterli görüssme ve katılım ile sağlanan veriler, alan akademisyenleri tarafından değerlendirilmiş, gerek görülen yerlerde düzeltmeler yapılarak sağlanmıştır. Dış gerçeklik için, görüşmelerin betimlenmesi ve görüşülen Isparta kebapçı esnafi/lokanta işletme yöneticilerinin/ çalışanlarının özgün ifadeleri dikkate alınmıştır. Bunun için, özel notlar, yöneticinin katıldığı uygulamalar (seminerler, programlar, sertifikalar, teftiş izlenimleri, raporlar, işlem süreçleri, prosedürleri, protokolleri, eğitim kılavuzları gibi) ve belgeler 
dışında/bağlantılı dış belgeler, sektör bilgileri, raporları, haber bültenleri vs. her türlü bilgi ve belge dikkate alınmıştır. Elde edilen tüm bilgi, belge ve verilerin düzeybilgileri oluşturulmuş ve tutarlılık sağlanmıştır.

(b) İkinci aşama, Isparta kebapçı esnafi/lokanta işletmelerinin sürdürülebilir rekabet anlayışı temel yetenekler ölçek temelinde [nicel] araştırılmıştır. Araştırma için yazında daha önce kullanılmış ve Chabert'in (1998) hazırlamış olduğu ölçekten yararlanılmıştır. Ayrıca ölçek veri kalitesi için kebapçı esnafi/lokanta işletmelerinde ön-uygulamalar yapılmış, ölçek gözden geçirilmiş ve ölçek etkinliğine yönelik öneriler değerlendirilmiş ve anketin uygulamaya ilişkin gerçekliliği sağlanmıştır.

Ölçekte yer alan soru ifadeleri ve temel yeteneklere ilişkin bileşenler dört düzeybilgi kapsamında ele alınmış ve sınanmıştır. Bunlar; (a) Teknik beceriler (technical skills-yemek hazırlanması, ortamı, kalitesi, sunumu, geri bildirim ve günlük işlemleri kapsayan 24 soru), (b) Yönetim becerileri (management skills-planlama, organizasyon, yöneltme, eşgüdümleme ve denetimi kapsayan 23 soru), (c) Sunum yetenekleri (server skills-stil, iletişim ve çalışmayı kapsayan 17 soru), (d) Pişirme becerileri (cook skills-teorik ve uygulama yemek pişirme bilgisi, isteği, deneyim, disiplin, organizasyonu kapsayan 17 soru) olarak dört düzeybilgide toplam 81 ifade yer almaktadır. Ayrıca, temel yetenekleri geliştirmede iletişim, ekip çalışması, tedarik ve diğer yardımcı konular ile ilgili beşinci düzeybilgi sorusu ve işletmelerin nakit akışı ve doluluk oranlarını gözlemek ve öğrenmeye ilişkin yardımcı soru ifadelerine yer verilmiştir. İfadeler 5'li Likert ölçeğine göre hazırlanmıştır.

Isparta kebapçı esnafi/lokanta işletmelerinin sürdürülebilir rekabette temel yetenekleri belirlemeye ilişkin ölçekte, geçerlilik ölçme türlerinden biri olan içerik ve yüzeysel geçerlilik kullanılmış (DeVellis, 1991; Netemeyer, Bearden, Sharma, 2003); buna göre uygulanan ölçeğe ilişkin ifadelerin ilgili yazından alınmış olması ve uygulama öncesinde akademik görüşlerden ve önerilerinden yararlanılması ve ölçeğin bu yönde uygulanması ile içeriksel ve yüzeysel geçerlilik değerlendirilmiştir. Ayrıca bu bağlamda geliştirilmiş ölçeğin güvenilirliğinin belirlenmesi için ${ }^{13}$ Cronbach alfa katsayısına bakılmış ve tüm değerlerin 0,65 ile 0,85 arasında değişmesi kullanılan ölçeğin içsel tutarlılığının sağlandığını göstermektedir. Elde edilen verilerin değerlendirilmesinde SPSS 21 istatistikî paket programından yararlanılmıştır. Veriler ağırlıklı ortalamalar yöntemi ile değerlendirmiş ve sonuçlar yorumlanmıştır.

Araştırma Verilerin Analizi: Sözlü tarih çalışmasına yönelik nitel veri analizinde, Miles ve Huberman (1994)'in eşzamanlı üç faaliyet akışından oluşan, veri azaltma, veri görüntüleme ve sonuç çizimi/doğrulama tekniği yorumlayıcı bir çerçevede değerlendirilmiştir: (bkz. Miles, Huberman, 1994 ) (a) Veri azaltma, veriyi seçme, odaklanma, basitleştirme, soyutlama ve dönüştürme sürecidir. Bu süreçte özetler yapma, kodlama, not yazma, temalar belirleme vb. çeşitli yazma biçimleri kullanılmıştır. Ayrıca süreçte gerekli olacak verilerin ortaya çıkarılması hedeflenmiştir, yeni bir metin yazımı için kimden nasıl veri alınacağı saptanmış ve kaynağa müracaat yapma yolu izlenmiştir.

\footnotetext{
${ }^{13}$ Anket soruları toplam korelasyon değerleri incelenmiş ve 0,50 'den düşük değere sahip olanlar düşürülerek, ölçeğin geliştirilmesi sağlanmıştır. O halde tüm cevap şıkları, yeterli soru korelasyon değerine ulaştıkları görülmüştür.
} 
Yapılan özetler ile veriler toplandıkça seyrekleştirilmiş ve doğrulması yapılmış; eksik kısımlar tamamlanmıştır. (b) Veri görüntüleme, verilerin sistematik hale gerilerek, sonuç çıkarma yönünü niteler. Bir bakıma indirgenmiş bir anlatı metini ile aşırı yük önlenmeye çalışılmıştır. Bu amaçla makalenin temel araştırma sorusu sürdürülebilir rekabette temel yetenekler konusunda veriler gruplandırılmıştır. (c) Verilerin eksik olup olmadığ 1 ve farklı yapılar içinde nasıl yer aldığına dair tüm verilerin toplu olarak görüntülenmesi notlar, temalar, metaforlar, saymalar ile veriler içinde desenleri incelemek olanağı sağlanmıştır. Üç kebapçı esnafi/lokanta işletmeye ilişkin elde edilen bilgi birleştirilerek sözlü tarih anlatısı şeklinde yorumlanmıştır. Bu nedenle birleşik sözlü tarih çalışması tümevarımlı bir yol olarak düşünülmüştür.

Sözlü tarih [etnografik görüşme] için elde edilen bilgidökümün (transkript) niteliksel analizi (Yow, 1994) temel yeteneklerin sürdürülebilir rekabetteki rolünü anlamada yardımc1 olacak kavramlar ve temalar belirlenmesinde kolaylık yaratmıştır. Sözlü tarih çalışmaları [görüşmelerde 3 kişi, fotoğraflama konusunda 2 kişi olmak üzere] toplam 5 kişi tarafindan yapılmıştır. Ancak daha önce sözlü tarih çalışmasının nasıl yapılacağ konusunda bilgi ve görgü paylaşılmıştır. İşletme sahipleri, yöneticileri ve çalışanları ile yapılan görüşmelerde sözlü tarih ölçütleri içinde tekrarlı ve çapraz kontrollere bağlı veriler tekâmül ettirilmiştir. Etnografik gözlemler, anlatı görüşmeleri ve yapılan bilgidöküm istişareye bağlı sözlü tarihleme için kullanılmıştır. (bkz. Lieblich, Tuval-Mashiach, Zilber, 1998) Niteliksel analizde anlatıların yapısına değil, içeriğine odaklaşılmış ve tümevarımlı bir yaklaşım izlenmiştir. Görüşme yapılan katılımcıların \% 95'i, kendilerinin tarihi bir lokantada çalışmanın bilincinde olarak konuşmaktan memnun oldukları görülmüştür. Ayrıca görüşme notlarının güven esasında paylaşımlı teyit sağlanmış; teyitli paylaşım (confirmed share) notlarından, Isparta kebapçı esnafi/lokanta işletmelerinin düzeybilgileriyle bütünleşik sözlü tarihi yazılmıştır.

Nicel araştırma nitel araştırma verilerinden elde edilen bulgulara bağlı, oluşan temaların (becerileri, varlıkları ve teknolojileri) sağlamasını yapmak ve özellikle sözel yönlerin niceliksel olarak ortaya koymak için, ölçek yardımıyla tedrici ve nitel araştırma eşgüdümlü toplanmış, 5'li Likert tipi ölçek ile temel yetenekler ve bağlantılı konulara dair veriler karşılaştırmalı değerlendirilmiş, süreçte bilgisayar olanakları azami şekilde kullanılmıştır.

\section{Araştırma Verilerinin Değerlendirilmesi}

a) Nitel Araştırma Verilerin Değerlendirilmesi: Isparta ili Kebapçı esnafı/lokanta Işsletmeciliği Sözlü Tarih Anlatısı. Isparta iline kebap esnafi/lokanta işletmeciliğinin nereden ve ne şekilde geldiği bilinmemesine rağmen, Selçuklu İmparatorluğu'na dayandığına/öne sürüldügüne ilişkin yaygın bir kabul vardır. Ancak bugüne ilişsin Isparta'da kebap esnafi/lokanta işletmeciliği faaliyetinde bulunan küçük/orta ölçekli aile işletmelerin kuruluş tarihleri dikkate alındığında, ilde yaklaşık 300 seneden daha fazla kebap esnafi/lokanta işletmeciliği yapıldığı rahatlıkla kabul edilebilir. (Böcüzade, Isparta Tarihinde Isparta'da yapılan 32 meslekten, 24. sırada kebapçılık olarak verir. bkz. Böcüzade, 1983: 420; ayrıca bkz. Kodaman, Babacan, 1998)

Isparta ili Kebapçılar ve Lokantacılar odasına bağl1-kayıtlı [2019 Mayıs verilerine göre] 145 işletme kebapçılık ile uğraşmakta, ve/fakat söz konusu işletmelerin gerçek anlamda 
kebapçılık işi ile ilgili Isparta Ticaret Odasına kayıtlı ve kuruluş yılları itibariyle 1800'lü yılların ikinci yarısına kadar varan, üç aile işletmesi [bunlar; Kebapçı Hacıbenlioğlu, Kebapçı Kadir ve Kebapçı Ferah] faaliyetini sürdürmektedir. ${ }^{14}$ (bkz. Tablo 3) Daha eskiden Isparta'da bu üç kebap esnafi/lokanta işletmesi dışında Kebapçı Muammer ve Kebapçı Azmi gibi tanınmış kebapçı esnafi/lokanta işletmesinden söz edilmektedir. (ayrıca bkz. Kaplan, 2010)

Tablo 3: Isparta İli Kebap Esnafi/Lokantacılığı ile ilgili Üç İşletme

\begin{tabular}{|c|c|c|c|c|c|c|c|}
\hline Kebapçı & $\begin{array}{l}\text { Kuruluş } \\
\text { tarihi }\end{array}$ & Kurucu ata & $\begin{array}{l}\text { İşletme } \\
\text { sahibi/kuşak }\end{array}$ & $\begin{array}{l}\text { Kapalı } \\
\text { alan }(\mathrm{m} 2)\end{array}$ & $\begin{array}{l}\text { Sabit } \\
\text { Çalışan } \\
\text { Sayısı } \\
\end{array}$ & Ürün portföyü & Temel amaç ifadesi \\
\hline $\begin{array}{l}\text { Kebapçı } \\
\text { Hacıben- } \\
\text { lioğlu }\end{array}$ & 1833 & $\begin{array}{l}\text { Hacibenlioğlu } \\
\text { Mustafa }\end{array}$ & $\begin{array}{l}\text { Mustafa } \\
\text { Gülata } 4 . \\
\text { Kuşak }\end{array}$ & $\begin{array}{l}280 \\
(2 \text { katlı } \\
\text { bina) }\end{array}$ & $\begin{array}{l}4 \text { Usta+4 } \\
\text { Yardımc1 } \\
\text { eleman }\end{array}$ & $\begin{array}{l}\text { Ana ürün Kebap yanısıra; Şiş Köfte, } \\
\text { Pide çeşitleri, Tahin Helvası ve Tel } \\
\text { Kadayıf }\end{array}$ & Lezzeti ve tadı korumak \\
\hline $\begin{array}{l}\text { Kebapçı } \\
\text { Kadir }\end{array}$ & 1851 & Hafiz Dede & $\begin{array}{l}\text { Hüseyin } \\
\text { Açıkalın } \\
5 . \text { Kuşak }\end{array}$ & $\begin{array}{l}360 \\
(3 \text { katlı } \\
\text { bina) }\end{array}$ & $\begin{array}{l}15 \text { Usta+10 } \\
\text { Yardımcı } \\
\text { eleman }\end{array}$ & $\begin{array}{l}\text { Ana ürün Kebap yanısıra; Şiş Köfte, } \\
\text { Pide çeşitleri, İskender, Tahin } \\
\text { Helvası ve Künefe }\end{array}$ & $\begin{array}{l}\text { Gelecek nesillere işi } \\
\text { aktarmak }\end{array}$ \\
\hline $\begin{array}{l}\text { Kebapçı } \\
\text { Ferah }\end{array}$ & 1944 & Hac1 Nuri & $\begin{array}{l}\text { Nuri } \\
\text { Parlar } \\
\text { 4. Kuşak }\end{array}$ & $\begin{array}{l}175 \\
\text { (3 Katlı } \\
\text { bina) }\end{array}$ & $\begin{array}{l}5 \text { Usta+7 } \\
\text { Yardımcı } \\
\text { eleman }\end{array}$ & $\begin{array}{l}\text { Ana ürün Kebap yanısıra; Şiş Köfte, } \\
\text { Pide çeşitleri, Tahin Helvası ve Tel } \\
\text { Kadayıf }\end{array}$ & $\begin{array}{l}\text { İşletmenin } \\
\text { markalaşmasını ve } \\
\text { kurumsallaşmasını } \\
\text { sağlamak }\end{array}$ \\
\hline
\end{tabular}

Kaynak: İşletme görüşme bilgileri (2017-2021).

Şehirde kebapçı esnafi/lokanta işletmeciliği ve aşçılık mesleği eskiden esnaf birliği olarak bilinen "ahilik" geleneği ile usta-kalfa-çırak yetiştirme ve geliştirme süreci ile günümüze geldiği izlenmektedir. (bkz. https://isparta.ktb.gov.tr/TR-71193/isparta-un-dergisi.html ) Ancak şimdilerde kebapçı esnafi/lokanta işletmeciliği ve aşçılık mesleği, daha ziyade bürokratik işlemlerin çoğaldığı ve sertifikalara bağlı yapılan ticari bir dönüşüm ile farklılaştığı görülebilir.

Fotoğraf 1: Isparta Kebap, Firıncı ve Helvacı Esnafi (1928)

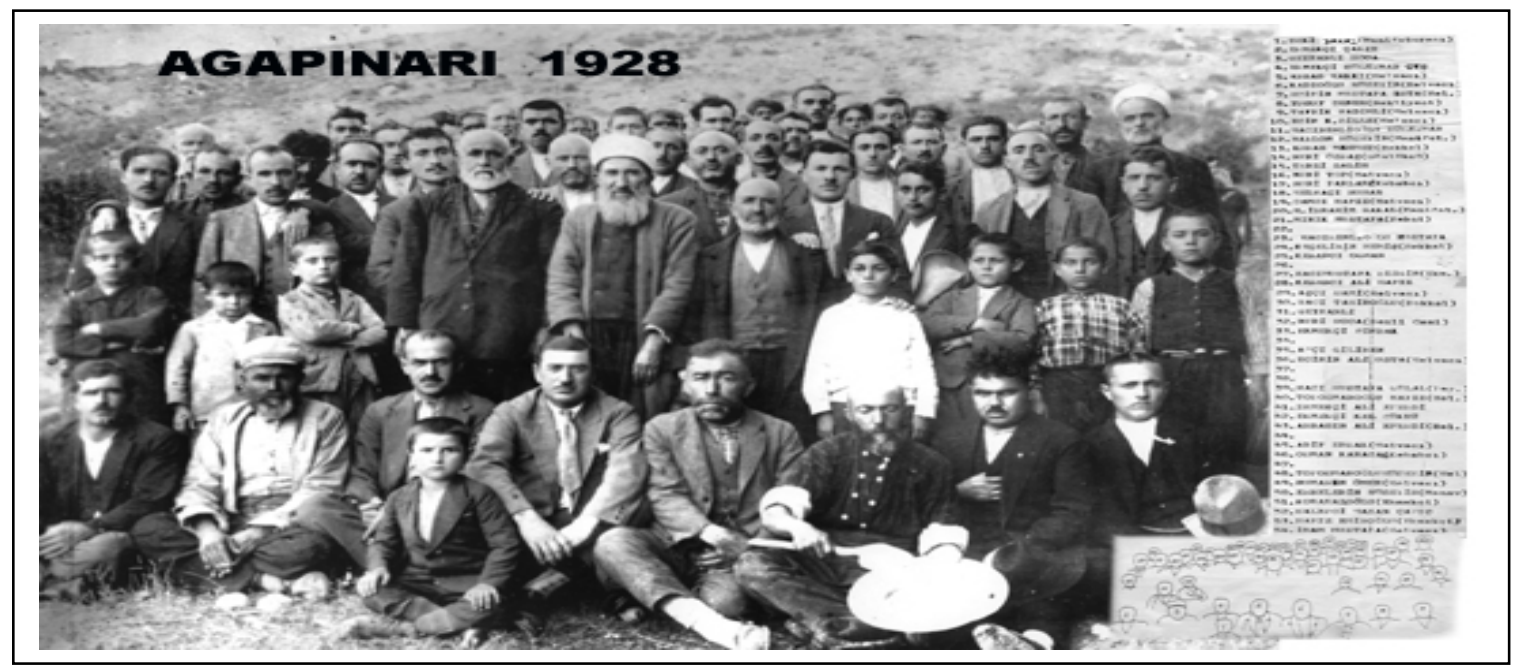

\footnotetext{
${ }^{14}$ Kebapçı Ferah, esnafların yoğun faaliyet gösterdiği Üzümcüler Pazarı'nda; Kebapçı Kadir ve Kebapçı Hacıbenlioğlu ise, Üzümcüler Pazarı'nın hemen karşısında [eski adı ile] Kebapçılar Arastası'nda yer almaktadır. Ancak Kebapçılar Arastası'nın yıkılmasından sonra, bu iki kebapçı yeniden tasarlanan aynı bölgede/yeni yerlerinde faaliyetlerini sürdürmektedir. (Not. Makalenin yayın tarihi itibariyle Kebapçı Ferah da, Üzümcüler Pazarı'ndan (2021 Nisan) yeni yeri: Kutlubey Mah. 120. Cad, Atatürk Parkı içi No.13, 32100 Isparta Merkez/Isparta) olarak taşınmıştır.) $b k z$. ekler Fotoğraflar.
} 
Isparta'da gerçek anlamda kebapçı esnafi/lokanta işletmeciliği ve aşçılık mesleği dönüşümü, son 35-40 yıl içerisinde kendini göstermiş̧ir. Sosyo-ekonomik ve sosyo-kültürel nedenlerle birlikte gelenekten uzak/artan işletme sayısına, değişen toplum ihtiyaçlarına ve mutfak/yemek kültürüne bağl geleneksel kebapçl1ıkta yer almayan çeşitler de menülere dahil edilmeye başlamıştır. Çok eskiden kebap esnafi/lokanta işletmelerinde sadece kebap pişirilip, domates-soğan ve Davraz dağından getirilen karlar ile soğuk içim hoşaf eşliğinde servis edilirken, zamanla şiş köfte, İskender kebabı, pide çeşitleri, farklı salatalar, soslar hatta sulu yemekler [geleneksel kalaylı bakır kaplarda] servis edilmektedir. (bkz. Kardüz, 2001)

Geçmişte Isparta kebabı (tandır) yemek için belirli zaman gözetilirken, şimdilerde gözetilmediği izlenir. ${ }^{15}$ Oysa gelenekte her zaman kebabın yenmediği ve yapılmadığı bilinir. Kebap için mevsiminde ve yörede yetişen davar [tam yağlı ve orta yağlı oğlak] eti esastır. (bkz. Şenol, 2003: 82-82; ayrıca bkz. Ak, 2007; Yaşin, 2008) Bu nedenle tüm y1l boyunca kebabın yapılması, doğal olarak Isparta kebapçılığında geleneksel lezzetin hızla kaybedilmesine iliş̧in endişeleri artırmaktadır. Bu endişeye azalan hayvan popülasyonu, çayır-mera kanunları yetersizliği, haksız rekabet, azalan gelir, değişen yeme alışkanlıkları ve buna karşılık kebapç1lı̆̆ yozlaştırma girişimleri gibi birçok faktör çarpan etki yapmaktadır. Ancak günümüz Isparta'sında geleneksel kebap lezzetine özen gösteren müşsteriler yanında, araştırmaya konu olan üç kebapçı esnafi/lokanta işletmesinin [mesleki bilgide geleneğe ve klasik ölçütlere bağlı] ısrarlı çalışmaları bulunmaktadır.

Daha ziyade kebapçı esnafi/lokanta işletmeleri rekabete karşı büyütmekten ve faaliyet ölçeğini artırmaktan ziyade, küçülmeye, ve/fakat faaliyet etkinliği ve kaliteyi yükseltmeye ve temel yeteneklerini korumaya çalıştı̆̆ gözlemlenmektedir. Bu yüzden kebapçı esnafi/lokanta işletmeleri aile imalathanesi özelliğini koruyan, ürün kalitesini ve müşteri memnuniyetini birinci planda tutan bir mesleki/ticarî anlayış hakim düşünce olarak kabul edilmektedir. Bu sayede hem marka (tanınmışlığı) sürekliliğini koruma, hem de geleneksel [örtülü (tacid knowledge)] bilginin aktarımı hedeflenmektedir. Ancak tüm bunlar, kebapçı esnafi/ lokanta işletmelerinin gelecek rekabetinde daha farklı ve ötede çalışmalar içinde bulunması gerektiğini işaret ettiği açıktır.

Kebapçı esnafi/lokanta işletmelerinde tedarik ve pazarlama faaliyetleri [değer zinciri] ailenin şu anki mesleği devam ettiren kuşakları tarafından yapılmaktadır. Halen entemel girdi olan etten başlayıp, kullanılan malzemeye sözgelimi domates ve soğana, hatta serviste ve paketlemede kullanılan materyallerin kalitesine kadar her şey ailenin şu anki kuşağı tarafından kontrol edilmekte ve özenle sağlanmaktadır.

Ortalama günde 10-15 oğlak/davar kebabı satılan işletmelerde yapım-teknik konusunda modern anlayışlar ve yenilikler uygulansa da, süreçte etin bilinen ve eski tedarikçilerden teminine ve satın alınmasına, taş firında geleneksel pişirme yöntemlerinin kullanılmasına, kebap odununun seçimine ve bu odunlarla etin en iyi şekilde pişirilmesine, zaman/1s1 hararetinin iyi ayarlanmasına geleneksel uygulamalara azami dikkat edilmektedir. (bkz. Hürmüzlü, 2019) Yanı sıra mutfak ekipmanları ile yeni çıkan pişirme teknolojileri de özellikle değerlendirildiği görülür. Sosyal olarak, gerek işletme sahipleri ile çalışanlar

\footnotetext{
${ }^{15}$ 25-30 yıl önceye kadar kebap sezonun başladığına ilişkin, kebapçı esnafi/lokanta işletmeleri herkesin görebileceği şekilde "kebap başladı" ilanı asmaktaydı.
} 
arasında ruhsal-duygusal boyut (ağabey-kardeş diyalogu), gerekse işletme çalışanları ile müşteriler arasında rasyonel-bilişsel boyut (saygı esaslı diyaloglar) layıkıyla değerlendirilmektedir.

Kebapçı esnafi/lokanta işletmelerinin yerleşik bir geleneğe sahip [usta-çırak veya ahilik geleneğine dayalı] olarak işleyişi, bu mesleğin küçük yaşlarda öğretilmeye başlanması, geleneğe sahip çıkmasında etkili olmaktadır. Diğer bir deyişle küçük yaşlardan mesleğe meraklı gençlerin yetiştirilerek usta yapılması ve oluşturulan ekiple uzun süreli çalışma sağlıklı işleyişi güçlendirmektedir. Yanı sıra geleneksel kebapçılık bilgisinin nesilden nesile, kuşaktan kuşağa aktarımı, kaliteyi ön plana alan ve bunlardan taviz vermeyen hizmet anlayışı, malzeme tedarikçileriyle uzun süreli çalışma ve korunan değerli müşteri potansiyeli olumlu etkileri izlenmektedir.

Ancak günümüz lokanta işletmeciliği ve anlayışında abur-cubur yeme (fast-food) kültürünün egemen oluşu, işletme menülerini bozmuş, bir kargaşa yaşanmasına yol açmıştır. Sulu yemek yapan bir dükkânda 1zgaraya, kebapçı olarak adlandırılan lokantacının da sulu yemek sunması gibi uygulamaları doğallaşmıştır. Böyle olunca, kendi sahasında ehil olmayan kişilerin yaptığı kebapların [öz veya hakiki ibareleri ile] geleneksel Isparta kebabı şeklinde sunulması, "kalitesizliğin maliyetini”" artırmakta ve gerçek Isparta kebapçı esnafi/lokanta işletmelerini zor duruma düşürmektedir.

(b) Nicel Araştırma Verilerinin Değerlendirilmesi: Isparta kebapçı esnafi/lokanta işletmelerinin sürdürülebilir rekabette temel yetenekler ve geliştirilmesine ilişkin uygulanan ölçekte; (a) teknik uygulamalar, (b) yönetim becerileri, (c) sunum yetenekleri ve (d) pişirme becerileri değerlendirilmiştir. Buna göre veriler [birinci işletme A işletmesi, ikinci işletme $\mathrm{B}$ işletmesi ve üçüncü işletme $\mathrm{C}$ işletmesi olarak kodlanmış olarak] analiz edilerek Tablo 4'de sonuçlar verilmiştir.

Tablo 4: İşletmelerin Karşılaştırmalı Temel Yetenek Analizi

\begin{tabular}{|l|l|l|l|l|l|}
\hline A İşletmesi & $\bar{X}$ & B İşletmesi & $\bar{X}$ & C İşletmesi & $\bar{X}$ \\
\hline Teknik Uygulamalar & 4,58 & Teknik Uygulamalar & 4,50 & Teknik Uygulamalar & 4,50 \\
\hline Yönetim Becerileri & 4,57 & Yönetim Becerileri & 4,57 & Yönetim Becerileri & 4,57 \\
\hline Sunum Yetenekleri & 4,53 & Sunum Yetenekleri & 4,59 & Sunum Yetenekleri & 4,65 \\
\hline Pişirme Becerileri & 4,71 & Pişirme Becerileri & 4,59 & Pişirme Becerileri & 4,76 \\
\hline
\end{tabular}

Tablo 4'e göre 3 işletmenin temel yetenekleri değişiklik göstermektedir. Şöyle ki: A işletmenin teknik uygulama ortalaması $(4,58), \mathrm{B}(4,50)$ ve $\mathrm{C}(4,50)$ işletmelerine göre yüksek olduğu görülmektedir. A, B ve $C$ işletmelerinin yönetim becerileri ortalamasının ise $(4,57)$ eşit olduğu görülmektedir. Sunum yetenekleri ortalaması, C işletmesinde $(4,65), B$ işletme işletmesinde $(4,59)$ ve A işletmesinde $(4,53)$ farklı olduğu görülmektedir. Sunum yeteneklerinde $\mathrm{C}$ işletmesi ortalaması $\mathrm{A}$ ve $\mathrm{B}$ işletmesine göre daha yüksektir.

Pişirme becerileri otalaması, $C$ işletmesinde $(4,76)$, A işletmesinde $(4,71)$ ve B işletmesinde $(4,59)$ farklı olduğu görülmektedir. Sunum yeteneklerinde $\mathrm{C}$ işletmesinin ortalaması A ve B işletmesine göre daha yüksektir. 
Yapılan analizine göre $\mathrm{C}$ işletme yetenekleri $\mathrm{A}$ ve $\mathrm{B}$ işletmesine oranla daha iyi olduğu söylenebilir. $\mathrm{Bu} \mathrm{C}$ işletmesinin nispeten yakın geçmiş kuruluşu ve modern lokanta işletme bilişimine sahip altyapısından kaynaklanabilir.

Isparta kebapçı esnafi/lokanta işletmelerinin sahip olduğu temel yeteneklerin geliştirilmesinde karar vericilerin rolü analizi sonuçları Tablo 5'de verilmişstir.

Tablo 5: İşletmelerde Temel Yeteneklerin Karar Vericileri

\begin{tabular}{|l|l|l|}
\hline A İşletmesi & B İşletmesi & C İşletmesi \\
\hline 1.Genel Müdür/yaşayan ata-sahip & 1 Aşçlar & $\begin{array}{l}\text { 1. Genel Müdür/yaşayan ata-sahip, Birim } \\
\text { Müdürleri, Servis Elemanları ve Aş̧̧lar }\end{array}$ \\
\hline 2. Aşçllar & $\begin{array}{l}\text { 2. Genel Müdür/yaşayan ata-sahip, Birim } \\
\text { Müdürleri ve Servis Elemanları }\end{array}$ & \\
\hline 3. Birim Müdürleri ve Servis Elemanları & & \\
\hline
\end{tabular}

Tablo 5'e göre işletmelerde temel yeteneklerin yürütülmesinde; A işletmesinde genel müdür/yaşayan ata-sahip birinci sırada karar verici olurken, ikinci sırada aşçılar, üçüncü sırada birim müdürleri ve servis elemanları karar verici durumundadır.

B işletmesinde birinci sırada aşçılar, ikinci sırada genel müdür/yaşayan ata-sahip, birim müdürleri ve servis elemanları karar verici durumundadır. Aşçıların birinci sırada yer alması, onların işletmenin temel yetenekleri oluşturması ile bağlantılı değerlendirilebilir.

$\mathrm{C}$ işletmesinde, genel müdür/yaşayan ata-sahip, birim müdürleri, servis elemanları ve aşçılar eşit düzeyde karar verici durumundadır.

Isparta kebapçı esnafi/lokanta işletmelerinin sürdürülebilir rekabette temel yetenekler ile ilişkili faktörler, 4 boyutlu değerlendirilmiş ve analiz sonuçları Tablo 6' da verilmiştir.

Tablo 6: İşletmelerde Temel Yetenekler ile İlişkili Faktörlerin Karşılaştırılması

\begin{tabular}{|c|c|c|c|c|c|}
\hline A işletmesi & $X$ & B işletmesi & $X$ & $\mathrm{C}$ işletmesi & $\bar{X}$ \\
\hline \multicolumn{6}{|c|}{ İşletmelerde Temel Yetenekleri Geliştirmede İletişim } \\
\hline $\begin{array}{l}\text { 1.Özel Uydu yayınları E-posta, Haber } \\
\text { Bültenleri, Müssteri raporları, Yöresel } \\
\text { müdürler, Bölge başkan yardımcıları } \\
\text { ve çalısmaları, Başkan yardımcıları } \\
\text { ve Toplantılar } \\
\text { 2. Sesli posta, Diğer teftişler, Kısa } \\
\text { notlar ve işletme yöneticileriyle yüz } \\
\text { yüze görüş̧me }\end{array}$ & 4,66 & $\begin{array}{l}\text { 1. Haber bültenleri, Müssteri raporları, } \\
\text { Toplantılar ve işletme yöneticileriyle } \\
\text { yüz yüze görüşme } \\
\text { 2. Diğer teftişler, Kısa notlar, yöresel } \\
\text { müdürler, Bölge başkan yardımcıları } \\
\text { ve çalışmaları ve başkan yardımcıları } \\
\text { 3. özel uydu yayınları, sesli posta ve } \\
\text { e-posta }\end{array}$ & 4,08 & $\begin{array}{l}\text { 1. Özel uydu yayınları, haber bültenleri, } \\
\text { müşteri raporları, diğer teftişler, yöresel } \\
\text { müdürler, Bölge başkan yardımcıları ve } \\
\text { çalışmaları, başkan yardımcıları, } \\
\text { Toplantılar, işletme yöneticileriyle yüz } \\
\text { yüze görüşme ve çalış̧alar ile sürekli } \\
\text { iletişime açık olma } \\
\text { 2. Sesli posta, E-posta ve Kısa notlar }\end{array}$ & 4,77 \\
\hline \multicolumn{6}{|c|}{ İşletmelerin Temel Yetenekleri Yürütmek için Olușturdukları Gruplar } \\
\hline $\begin{array}{l}\text { 1. Müssteri odak grupları, Yorum } \\
\text { kartları ve müssteri raporları } \\
\text { 2. Eğitim videoları }\end{array}$ & 4,75 & $\begin{array}{l}\text { 1. Müşteri raporları } \\
\text { 2. Müsțeri odak grupları, yorum } \\
\text { kartları ve Eğitim videoları }\end{array}$ & 4,25 & $\begin{array}{l}\text { 1. Müssteri odak grupları, Yorum kartları } \\
\text { ve müşteri raporları } \\
\text { 2. Eğitim videoları }\end{array}$ & 4,75 \\
\hline \multicolumn{6}{|c|}{ İşletmelerin Temel Yetenekleri Geliştirmede Yardımcı Olacak Konular } \\
\hline $\begin{array}{l}\text { 1. Kişisel bilgisayarlar, lokanta } \\
\text { tasarım ekibi, lokanta örnekleri, } \\
\text { mutfakla ilgili takımlar, mutfak } \\
\text { dizayn örnekleri, test mutfakları ve u- } \\
\text { şekli mutfaklar } \\
\text { 2. Eğitim merkezleri, sertifikalı } \\
\text { eğitim mağazaları }\end{array}$ & 4,77 & $\begin{array}{l}\text { 1. Lokanta örnekleri ve mutfak } \\
\text { tasarım örnekleri } \\
\text { 2. Kişisel bilgisayarlar, eğitim } \\
\text { merkezleri, lokanta dizayn ekibi, test } \\
\text { mutfakları, sertifikalı eğitim } \\
\text { mağazaları, mutfakla ilgili takımlar } \\
\text { ve u-şekli mutfaklar }\end{array}$ & 4,22 & $\begin{array}{l}\text { 1. Kisisisel bilgisayarlar, lokanta tasarım } \\
\text { ekibi, test mutfakları, mutfakla ilgili } \\
\text { takımlar, mutfak dizayn örnekleri ve u- } \\
\text { şekli mutfaklar } \\
\text { 2. Eğitim merkezleri, lokanta örnekleri } \\
\text { ve sertifikalı eğitim mağazaları }\end{array}$ & 4,66 \\
\hline \multicolumn{6}{|l|}{ İșletmelerin Kaynak Teminleri } \\
\hline $\begin{array}{l}\text { 1. Yeterli insan kaynakları, eğitim, } \\
\text { müssteri incelemeleri, yönetsel } \\
\text { yönetici yardımları, bütçesel } \\
\text { sağduyu, yenilenmiş ve değiştirilmiş } \\
\text { lokantalar ve konuk mektupları } \\
\text { 2. Teknoloji, pazar incelemesi ve } \\
\text { gizli alıcılar }\end{array}$ & 4,7 & $\begin{array}{l}\text { 1. Yeterli insan kaynakları, eğitim, } \\
\text { müssteri incelemeleri ve konuk } \\
\text { mektupları } \\
\text { 2. Teknoloji, pazar incelemesi, } \\
\text { yönetsel yönetici yardımları, bütçesel } \\
\text { sağduyu, yenilenmiş ve değiștirilmiş } \\
\text { lokantalar ve gizli alıcılar }\end{array}$ & 4,4 & $\begin{array}{l}\text { 1. Yeterli insan kaynakları, eğitim, pazar } \\
\text { incelemesi, müşteri incelemeleri, } \\
\text { yönetsel yönetici yardımları, bütçesel } \\
\text { sağduyu, yenilenmiş̧ ve değiştirilmiş̧ } \\
\text { lokantalar ve konuk mektupları } \\
\text { 2. Teknoloji ve gizli alıcılar }\end{array}$ & 4,8 \\
\hline
\end{tabular}


Tablo 6'a göre, işletmelerin temel yetenekleri geliştirmesinde kullanılan iletişim yöntemlerin ağırlıklarına göre, A işletme ortalaması $(4,66)$, B işletme ortalaması $(4,08)$ ve $\mathrm{C}$ işletme ortalaması $(4,77)$ farklıdır. $\mathrm{Bu}$ sonuçlara göre $\mathrm{C}$ işletmesinin temel yetenekleri geliştirmede iletişimin ağırlığı A ve B işletmelerine göre daha iyi olduğu görülmektedir. Ancak bu sonuçlar araştırmaya konu olan diğer kebapçı esnaf/lokanta işletmelerinin rekabette gerekli teknolojiye ve iletişime önem vermediği anlamında değerlendirilmemelidir. Belki en azından teknoloji alanlarını birleştirmede uygun kapasiteyi yakalamaya çalıştığı şeklinde yorumlanabilir. Çünkü teknolojinin uygulanması için pek çok şeyi birleştirmek gerekir.

Isparta kebapçı esnafi/lokanta işletmelerinin temel yetenekleri yürütmek için oluşturduğu grupların ağırlıklarına göre, A ve C işletmesinin ağırlıklı ortalamaları $(4,75)$ ile eşit olduğu görülürken, $\mathrm{B}$ işletme ortalaması $(4,25)$ ayrıldığı belirlenmiştir. $\mathrm{Bu}$ sonuca göre $\mathrm{A}$ ve $\mathrm{C}$ işletmesinin B işletmesine göre daha iyi olduğu söylenebilir. B işletmesinin ise, aldığ müşteri raporları beklenen etkiyi yaratmakta yeterli olmadığı saptanmıştır. Burada düşünülmesi gereken, müşteri grubunun istek ve ihtiyaçları doğrultusunda değişimin kaçınılmazlığıdır. Bağlamsallık değiştiği zaman strateji de değişebilmelidir.

Isparta kebapçı esnafi/lokanta işletmelerinin temel yetenekleri geliştirmede yardımcı olacak konuların ağırlıklarına göre, A işletmesi ağırlıklı ortalaması $(4,77)$, B işletme ortalaması $(4,22)$ ve $\mathrm{C}$ işletme ortalaması da $(4,66)$ farklı olarak belirlenmiştir. Bu sonuca göre $\mathrm{A}$ işletmesinin $\mathrm{B}$ ve $\mathrm{C}$ işletmelerine göre değer sunma şeklini etkileyecek teknolojik bileşimlerde daha iyi olduğu söylenebilir. $\mathrm{Bu}$ durum $\mathrm{A}$ işletmesinin teknolojiyi uygulayabilme yeteneğinden ve bunu kullanma konusunda profesyonel desteğe açık olmasından kaynaklanabilir.

Isparta kebapçı esnafi/lokanta işletmelerinin kaynak teminine yardımcı olan konuların ağırlıklarına göre, A işletmesi ağırlıklı ortalaması $(4,7)$, B işletme ortalaması $(4,4)$ ve C işletme ortalaması da $(4,8)$ farklı olarak belirlenmiştir. Bu sonuca göre $\mathrm{C}$ işletmesinin $\mathrm{A}$ ve $\mathrm{B}$ işletmelerine göre tedarik sistemleri ve süreçleri daha iyi kontrol ettiği söylenebilir. $\mathrm{Bu}$ temel yetenekleri geliştirmede iletişim başarısının bir uzantısı olarak görülebilir.

Ayrıca araştırmada Isparta kebapçı esnafı/lokanta işletmelerinin doluluk oranları bakımında da karşılaştırma yapılmış ve elde edilen sonuçlar Tablo 7'de gösterilmektedir.

Tablo 7: İşletmelerin Doluluk Oranları ve Nakit Akışı

\begin{tabular}{|l|l|l|l|l|l|}
\hline A İşletmesi & \% & B İşletmesi & $\mathbf{\%}$ & C İşletmesi & $\%$ \\
\hline Nakit Akışı & 55 & Nakit Akışı & 50 & Nakit Akış1 & 60 \\
\hline Doluluk Oranı & 85 & Doluluk Oran1 & 70 & Doluluk Oranı & 80 \\
\hline
\end{tabular}

Tablo 7'e göre C işletmesinin nakit akışı A ve B işletmesine oranla daha iyi konumdayken, doluluk oranlarına incelendiğinde $\mathrm{A}$ işletmesinin doluluk oranının $\mathrm{B}$ ve $\mathrm{C}$ işletmelerine oranla daha iyi olduğu görülmektedir. Ancak her işletme nakit akışını sağlamada yeterli düzeyde olduğu kabul edilebilir. Yanı sıra her üç işletme içinde nakit akışı ve doluluk oranı temmuz ayında olduğu belirlenmiştir. Bu oranlar, Isparta'nın tatil ayı ve tatil yerlerinin güzergâhında yer almasına bağlı yorumlanabilir. 


\section{Araştırma Bulgularının Genel Yorumu ve Tartışma Notları}

Modernleşme ile birlikte, toplumları yeniden kurma çalışmaları, derinleşen pazarlar, politikanın ticareti ve her alanda yaşanan "şeyleşme" yeni tartışmalara neden olmuştur. (bkz. Herman, 1995: 143-152) Eksen ilkeler, teknoloji, bilim ve kültürün etkisiyle özel mülkiyet ve sınıfsal ayrımların önceliğini vurgulamaktan vazgeçilerek, daha çok özgürlük, daha fazla özgünlük ya da daha fazla verimlilik gibi vurgular ile emek ve sermayenin yerine bilişim/bilgi, farklılığın ve benzersizliğin yerini aldığı görülmüştür. Bu nedenle oluşan toplumun farklı şekilde yorumlanmasına yol açmıştır.

Rekabet "ihtiyaç ekonomisi"nden yani, üretimi ve değişimi toplum bireylerinin ihtiyaçlarını gidermek üzere gerçekleştirilmesinden ziyade, şiddeti gittikçe artan ve bazılarına göre acımazsızca yaşandığı günümüz tüketimcilik anlayışına erişmiştir. Aslında sanayi devrimi sonrası (a) mal üretim sektöründen hizmet sektörü ekonomilerine doğru evrilmesi, (b) çalışma alanında, yapılan işin niteliğine göre teknik ve profesyonel sınıfın önemsenmesi, (c) gerekli yenilik ve politik kararlar vermek için kuramsal-stratejik bilginin öncelenmesi, rekabet anlayışının daha farklı düzeyde ele alınmasına yol açmıştır.

Rekabet anlayışı, açık strateji, fark yaratma ve benzersizliğe yönelmiş; farklı müşteri gruplarına, rakiplerinden daha farklı bir şeyin nasıl sunulacağı hakkında paylaşılan vizyon oluşturma gerekliliğini zorlamıştır. Kaldı ki, her işletmelerin aynı standartlar ve değişkenler ile faaliyetleri gerçekleştirme görece standardı yükseltse de, işletmelerin ilerleme ve rekabetçi üstünlüklerini sürdürme konusunda yeterli gelmemiştir. İlerlemek ve gelecekte yaşamak, stratejinin temeli olarak rekabetçi avantajı yaratmak olmaktadır. Bu nedenle işletmelerin yaptığı işte daha iyi olma ötesinde, farklı ve benzersiz olma zorunluluğu bulunmaktadir.

Ancak sürdürülebilir rekabette kebapçı esnafi/lokanta işletmeleri için farklılık ve benzersizlik vurgusu ya da evrensel/yerleşik bir strateji uygulama düşüncesinin yanlışlığ1 açıktır. $^{16} \dot{I y i}$ strateji (good strategy) kebapçı esnafi/lokanta işletmelerinin özgü/l konumlarına bağlıdır. O halde kebapçı esnafi/lokanta işletmelerinin sektör dinamiklerini ve gelecekteki yörüngesine bakması, sektörü kendi avantajlarına yönelik nasıl dönüştüreceği ile ilgilidir. $\mathrm{Bu}$ nedenle kebapçı esnafi/lokanta işletmelerinin her müşterinin istediğini karşılaması doğru olmaz. Strateji seçim yapmayı gerektirir. Kime ne tür bir değer sunulmasına karar vermek gerekir.

Öyle ise, kebapçı esnafi/lokanta işletmelerinin sürdürülebilir rekabet anlayış1; (a) sektör içinde özgü/l stratejiler geliştirme, (b) stratejilerde farklılık ve benzersizlik içerimi gözetme, (c) bu farklılığı ve benzersizliği sürdürme konusunda destekleyici uygulamalar ve eylemler gerçekleştirme beklenir. Eğer kebapçı esnafi/lokanta işletmeleri müşteriler için değer üretme ve sunma konusunda tutarlı bir yöntem izlemiyorsa, rekabetçi anlayış bulunduğu konumdan daha öte olmayacaktır. Oysa rekabette sürekli bir değişim yaşanır. Durum böyle

\footnotetext{
${ }^{16}$ Lokanta işletmeciliğinin Ango-sakson kültürü ve ABD eksenli değerlendirilmesi gerektiği düşünülebilir. Her ne kadar ABD'de de hızla bu tür işletmecilik ve alternatifleri söz konusu edilse de, gerçek anlamda Fransa kaynaklı bir yönelimden söz edilmektedir. Bu bağlamda sanayi devrimi sonrası, modernizmin artan etkisi ve kapitalizmin ivme kazanması özellikle değerlendirilebilir. Diğer bir deyişle her düşüncenin faydacı (pragmatik) yönünün değerlendirildiği ve tanınabilen bir yapı oluşturma düşüncesi ile lokanta işletmeciliğinin bugünkü gelişmiş düzeyine erişmesinde, modernizmin ve kapitalizmin önemli katkıları düşünülebilir. bkz. Bingöl, 2005: 31-34; ayrıca bkz. Henaut, Mitchell, 2020.
} 
olunca, işletmelerin en iyi yöntem, teknik ve fikirleri kullanma dişında farklı çalışmalar yapması gerekmektedir. Bu bir bakıma yeniliği üretme, temel yetenekleri geliştirme ve/hatta dönüştürme ile ilgilidir. (bkz. Gibson, 1997: 45-54)

$\mathrm{Bu}$ açıdan kebapçı esnafı/lokanta işletmelerinin geçmişte değerli olan işletme [iç (internal)] kaynaklarını sürekli iyileştirmesi, kaynakların taklidini önlemesi veya taklit edilmeyen/edilmesi yüksek maliyetli kaynaklara dayalı stratejiler geliştirmesi ve her şeyden önce örgütsel sorunlara yanıt verebilecek yetenek kompozisyonları (talent compositions) yaratması gerekir. Temel yetenekler, müşteri yararı/değeri sağlama, piyasa liderliğine erişme ve bu yönde geleceğin firsatlarına karşı işletmenin hazırlıklı olma konusunda önemli bir katkı sağlayacaktır. Ancak temel yeteneklerin iyileştirilmesi ve geliştirilmesinde benzersizlik veya taklit edilmezlik özelliğinin korunması başat olmalıdır. Çünkü o halde işletmeler diğer işletmelerden ayırt edilebilir/farklılaşabilir ve tanınabilir. Yani işletmeler sadece bir ürün/hizmet üzerine odaklaşmaktan öte, yetenek portföyünü (talent portfolio) geliştirici konum oluşturmayı düşünmesi beklenir. (Hamel, Prahalad, 1996: 285)

\section{Sonuç ve Öneriler}

Rekabet açıkça farklılık ve benzersizlik yaratacak stratejiler ve vizyon gerektirir. Yani rekabette sadece dezavantajı ortadan kaldırma veya rakibin alanını daraltıcı/bozucu strateji ve vizyon yeterli gelmez, avantajı dönüştürmek ve/dahası neler yapılabileceğini düşünmek gerekir. Çünkü her işletmenin aynı değişkenler ile rekabet avantajı yaratması mümkün değildir. Geliştirilecek stratejiler, rakiplerden daha farklı olmalıdır. Diğer bir deyişle işi daha iyi yapmak yanında, yaptığı işte farklı olanı yapmak gerekmektedir. Bu ise başlı başına stratejik ögrenme (strategic learning) süreci ile ilgilidir.

Stratejik öğrenme, bilinmesi gerekenleri bilme ve bunun için yeni öğrenim olanakları araştırma ve yaratma kapsamıdır. O halde bir işletmenin pazar payı düşük olsa da, yüksek kârlılığa nasıl sahip olduğunu görmek şaşırtıcı olmaz. Çünkü rekabette kazanmanın tek yolu pazar payının çoğunu ele geçirmek olmadığı açıktır. Yani evrensel ya da her yerde işletmelerin uygulayabileceği mutlak strateji uygulama düşüncesinin yanlışlığı ortaya çıkar.

Isparta kebapçı esnafi/lokanta işletmelerinin sürdürülebilir rekabette en gerçekçi yol, işletmelerin evrimini izlemesi ve işletmenin o sektördeki konumunu herhalde yeniden çatılandırması olarak düşünülebilir. Buna göre işletmeler sektör dinamiklerine bağlı gelecek yörüngelerine bakmalıdır. Ancak burada işletmelerin başarısı, yaptığı işin etkisini yükseltmek kapsamına dair olduğu da göz önüne alınmalıdır. Diğer bir deyişle, Isparta kebapçı esnafi/lokanta işletmelerinin genel lokantacılık değil, özgü/l kebapçılık (special kebabs) yapması gerekir. Buna göre işletmelerin geliştireceği stratejiler bir anlam ifade edebilir.

"İyi strateji” her zaman işletmeyi farklılaştırır. Çünkü iyi strateji, kendine özgü/l bir konum ve müşteri tabanı sağlar. Stratejibilimde işletmelerin her isteyenin/müşterinin isteğini karşılaması ve/dahi her şeyi sunması, geleneksel kebapçılık çerçevesinde tartışması gerekir. Strateji bir seçim süreci ise, işletme kime ne tür bir değer sunacağına karar vermelidir.

Öte yandan rekabette sadece farklı olmak da yeterli gelmeyebilir; bu farklılık diğer işletmeler ile uzlaşma/stratejik işbirliği içinde bulunmayı gerektirebilir. Aksi halde her ne yapıldıysa kolayca ve/hatta düşük maliyetle taklidin yapılmasına yol açabilir. 
Araştırma sonuçlarına göre Isparta kebapçı esnafi/lokanta işletmelerinin sürdürülebilir rekabette sektör performansının yüksek olması, sunduğu ürün ve sunulan hizmetin değerinden kaynaklandığı rahatlıkla izlenir. Bu nedenle süreklilik için geleneksel kebapçılık misyonunu önceleyerek, ana strateji ayrıntılarında tutarlı bir değişim yaratması büyük katkı sağlayabilir. Ayrıca Isparta kebapçı esnafi/lokanta işletmelerinin gerçekleştireceği yenilikler ve iyileştirme yaklaşımları, stratejik vizyon içerisinde değerli olabilir; çünkü bu yaklaşımlar kendilerini güçlendirecek farklı bir şey yapıldığını vurgulama olanağı verir. Ancak bu yaklaşım tarzı sürdürebilir rekabette yeniliği üretecek ve iyileştirmeleri yapacak öğrenimin temel yeteneklere dayalı yapılması gerekliliğini ifade ettiği unutulmamalıdır. (bkz. Gibson 1997: 45-54)

Sürdürülebilir rekabette temel yetenekler, Isparta kebapçı esnafi/lokanta işletmelerinde stratejik kaynağı yaratma veya var olan kaynağın varlık stokunu genişletme için [katalizör olarak] gerekli deneyim, bilgi ve sistem desteği yaratır ve/dahi yeteneklerin bir araya toplanmasını etkinleştirir. Eğer işletmeler, geçmişte geliştirdiği deneyim, bilgi ve sistem ile etkinliğini sağliyorsa, buna sahip olmayan işletmeye göre daha kolay ve daha az maliyetle varlıklarını yerine koyabilir. Ancak daha önce stratejik niyet (strategic intent) veya örgüt kaynaklarını ve yönetim enerjisini oluşturma ve geliştirme bilincini sağlamak, korumak ve sürdürmek iradesinin beyanı gerekir. Bu Isparta kebapçı esnafi/lokanta işletmelerinde çalışan herkesin özel/işletmeye özgü performans ölçütlerini izleme ve duyarlılıklarını canlı tutmasını işaret eder. Ne var ki, günümüz rekabet koşulları Isparta kebapçı esnafi/lokanta işletmelerinin, rekabet edebilecek özgül bir görüş [ve ayrıntılı tahmin etme zorluğu] adına daha fazla çaba göstermesini zorladığı açıktır. Eğer işletmeler rekabette sürdürülebilirlik istiyorsa, kendi kaderlerini ele alma konusunda temel yeteneklerini tanıması, koruması, geliştirmesi, iyileştirmesi, yeniden üretmesi veya yenilemesi kaçınılmaz bir görev olacaktır.

İşletmelere öneriler: Isparta kebapçı esnafi/lokanta işletmelerinin öncelikle temel yetenekler bağlamında öz olarak şu öneriler yapılabilir: (ayrıca bkz. Bingöl, 2005: 336-340)

- Güçlü bir istihbarat sistemi oluşturma, pazarda neler olup bittiğini buna bağlı zayıfgüçlü yanları değerlendirme,

- Müşteri değerini yaratma ve paylaşma ile müşteri memnuniyetini sağlama ve sürdürme,

- Sektör değişimlerini sürekli izlenme, ve/fakat gelenekselliği zedelemeyecek tarzda yeniyi değerlendirme,

- Her halükârda işte lider olma özelliğini izleme,

- Işletme marka değerini vurgulama ve uygulamaları geliştirme,

- Ürün kalitesini ve sürekliliğini gündemde tutma,

- Mekân ve atmosfer (ambiyans) uygulamalarını gelişen teknoloji ile birlikte değerlendirme.

Araştırmanın katkıları: Türk-Anadolu geleneksel mutfak ve yemek kültürü ideolojisi ve Türk lokanta işletmeciliği bağlamında geleneksel yemek aşçılığı olarak Isparta kebapçı 
esnafi/lokanta işletmelerinin sürdürülebilir rekabette temel yeteneklerinin incelendiği bu makale, alan yazınına ve uygulamaya yönelik katkıları şu şekilde düşünülebilir:

- Makale ile yazına ilişkin yerel düzeyde Isparta'da ve ulusal düzeyde ise Türkiye'de yapılan ilk-özgün çalışma olarak değerlendirilmiş ve bu konuda yapılacak/yapılması düşünülen çalışmalara temel oluşturacağı inancı korunmuştur. Uygulamaya dönük olarak rekabetçilik ve sürdürülebilir rekabet (rekabetçi avantaj ve üstünlük) için Isparta kebapçı esnafi/lokanta işletmelerinin yapması gereken faaliyetlerin içeriklendirilmesi ile gerek araştırmaya konu olan kebapçı esnafi/lokanta işletme yöneticilerine, gerekse benzer faaliyet gösteren diğer lokanta işletmelerine yönlendirici nitelikte olduğu düşüncesi benimsenmiştir. Bu nedenle makalede temel yeteneklerin sürdürülebilir rekabette yol gösterici olarak nasıl ele alınması gerektiği konusunda argümanlar sunulmuş; nelerin öncelikli ele alınacağı yapılan değerlendirmeler ile paylaşılmıştır. Yanı sıra 1800'lü yıllardan bu yana kesintisiz faaliyet gösteren Isparta kebapçı esnafı/lokanta işletmelerinin başarı öykülerini pekiştirme ve marka değerleri konusunda neler yapılabileceğine ilişkin de “akademik ilgi”"nin artırılmasına çalışılmıştır.

- Makale ile 1990’lı yillardan itibaren sosyal bilimlerde kullanılan ve son zamanlarda sıkça ifade edilen karma (mix) yöntemin, dezavantajına rağmen avantajlı yönlerini ortaya koymaya yönelik [bu uygulama ile temel (basic) düzeyde] gösterilmiştir. Doğal olarak makalede karma yöntem tasarım ve uygulamalarını ayrıntılı açıklamalarının tanıtlanması öncelenmiştir. Böylece karma yöntemin kullanımdeğeri için, alan çalışmalarında/yazında daha sonra yapılacak çalışmalar ile yöntemden kaynaklı mevcut dezavantajların etkisizleşeceği düşünülmüştür.

Yeniden düşünmeye ilişkin konular: $\mathrm{Bu}$ makale hem Türk-Anadolu geleneksel mutfak/yemek kültürü, hem Türk-Anadolu lokanta işletmeciliği ve/dahi [Isparta] kebapçı esnafi/lokanta işletmeciliği ve aşçılık mesleği konusunda bilimsel argümanlar sunmayı amaçlamış olsa da, araştırma ölçeğinin genişletilmesi, daha yoğun katılımlar ve karşılaştırmalı çalışmalar ile desteklenmesi ve boylamsal olarak izlenmesi, sonuçların genelleştirilmesi (bulguların bilgi haline dönüşmesi) açısından yararlı olacaktır.

Yanı sıra makale ile nitel kısmında kullanılan etnografik temelli daha gelişkin (sophisticated) yöntemlerin kullanılabilirlik seçeneği, daha sonra/farklı çalışmaların nasıllarını cevaplayacağı veya güdümleyeceği beklentisi korunmuş; o halde antropolojik yöntemlere olan ilgi ve elde edilen sonuçlara etkisi, nicel araştırma yöntemleriyle çapraz kontrollerin daha rahat yapılacağı düşünülmüştür.

Teşekkür ve İthaf: Makale için katkılarını esirgemeyen Türk-Anadolu geleneksel mutfak/yemek kültürü içinde Isparta kebapçı esnafi/lokanta işletme sahiplerine ve çalışanlarına; lojistik destekleri için Dr. Öğr. Üyesi Ahmet Songur'a, Doç. Dr. A. Buğra Hamşıŏglu'na ve A.İhsan Parlar'a teşekkür ederiz. Ayrıca makale, yazım sürecinde bilgilerine başvurulan 13 Eylül 2020 tarihinde Covid-19 nedeniyle vefat eden, öğretmen-şair, kültüradamı ve yazdığı çeşitli eserler ve çalışmalar ile gelecek nesillere sşık tutan (merhum) Sümer Şenol'a ithaf edilmiştir. 
Sürdürülebilir Rekabette Temel Yetenekler: Isparta Kebapçı Esnafi/Lokanta Işsletmelerinde Araștirma

\section{Kaynakça}

\section{I-Makale Kurulumunda İzlenen Kaynakları}

Ak, K. (2007), Osmanlı'dan Günümüze Türk Yemek Kültüründe Seramik Yemek Kapları, Eskişehir: Eskişehir Anadolu Üniversitesi Sosyal Bilimler Enstitüsü Seramik Ana Sanat Dalı (Yayınlanmamış YL Tezi).

Altan, Çetin (2006), "Memluk Devletinde Yemek Kültürüne Genel Bir bakış", Millî Folklor, 18, 72 : 107-117.

Altınay, R. (2006), İlk Dönem İslam Toplumunda Çalışma Hayat, Konya: Tablet Ya. Barney, J. A. (1997), Gaining and Sustaining Competitive Advantage, Mass: Addison-Wesley Publishing Company, Inc.

Baysal, A. (1993), “Türk Yemek Kültüründe Değiş̧meler, Beslenme ve Sağlık Yönünden Değişmeler", Türk Mutfak Kültürü Üzerine Araştırmalar, Ankara: Türk Halk Kültürünü Araştırma ve Tanıtma Vakfi Ya. No. 3: 12-20.

Baysal, A. vd. (1996), Türk Mutfağından Örnekler, Ankara: Kültür Bakanlı̆̆ı Ya. No. 1570.

Beardsworth, Alan, Keil, Teresa (2012), Yemek Sosyolojisi Yemek ve Toplum Çalışmasına Bir Davet (çev. Abdulbaki Dede), İstanbul: Phoenix Yayıncilık

Beşirli, H. (2021), Yemek Sosyolojisi: Yiyeceklere ve Mutfağa Sosyolojik Bakış, İstanbul: Phoenix Yayınevi.

Bingöl, R. (2005), Restoran İșletmeciliği, İstanbul: Timaş Ya. No.1238/50.

Boudan, C. (2004), Mutfak Savaşları (çev. Yaşar Avunç), İstanbul: Ayrıntı Ya. No. 501/19.

Böcüzade Süleyman Sami (1983), Isparta Tarihi, İstanbul: C.I-II, Serenler Ya.

Brannen, J. (2005), "Mixing Methods: The Entry of Qualitative and Quantitative Approaches into the Research Process", International Journal of Social Research Methodology, 8(3): 173-184.

Brillat-Savarin, J. A. (2016), Lezzetin Fizyolojisi ya da Yüce Mutfak Üzerine Düşünceler (çev. Heval Bucak), İstanbul: Oğlak Ya.

Câhız (1999), Cimriler Kitabı (terc. Yahya Atak), İstanbul: Şule Ya.

Campbell, J. R., Daft, R. L., Hulin, C. L. (1982), What to Study? Generating and Developing Research Questions, New Bury: Sage Publications.

Chabert, M. de (1998), A Model For The Development And Implementation Of Core

Competencies In Restaurant Companies For Superior Financial Performance, Blacksburg, Virginia: Virginia Polytechnic Institute and State University.

Civitello, L. (2019), Mutfak ve Kültür: İnsanın Beslenme Tarihi (çev. Z. Nilüfer Nahya, Saim Örnek), Ankara: Bilim ve Sanat Ya.

Creswell, J. W. (2013), Research Design: Qualitative, Quantitative, and Mixed Methods approaches, Thousand Oaks, CA: 2nd ed., Sage.

Daft, R. L. (1983), Organization Theory and Design, New York: Front Cover, West Publishing Company.

Dalby, A. (2014), Bizans'ın Damak Tadı: Efsanevi Bir İmparatorluğun Mutfağı (çev. Ali Özdamar), İstanbul: Alfa Ya. 
Sürdürülebilir Rekabette Temel Yetenekler: Isparta Kebapçı Esnafi/Lokanta Işsletmelerinde Araștirma

Davidson, A. (2014), The Oxford Companion to Food, UK: 3 edt., Oxford Univesty Press. DeVellis, R. T. (1991), Scale Development Theory and Applications, U.S.A.: 2nd Edition, Sage Publications, Thousand Oaks.

Douglas, M., Isherwood, B. (1998), Tüketimin Atropolojisi (çev. Erdem Attila Aytekin), Ankara: Dost Ya.

Eksen, İ. (2008), İstanbul'un Tadı Tuzu: Saray Sofralarından Sokak Yemeklerine, İstanbul: Everest Ya.

Erkara, O. (2010), 100 Tarihi Lokanta, İstanbul: Cinius Ya.

Featherstone, M. (1996), Postmodern Tüketim Kültürü (çev. Mehmet Küçük), İstanbul: Ayrıntı Ya.

Geertz, C. (1973), The Interpretation of Cultures: Selected Essays, New York: BasicBooks. Gibson, R. [der.] (1997), Geleceği Yeniden Düşünmek (çev. Sinem Gül), İstanbul: Sabah Ya. No. 46/15 içinde; Michael Porter, "Yarının Avantajlarını Anlamak": 45-54.

Gowlett, J. A. J. (2016), “The Discovery of Fire by Humans: A Long and Convoluted Process", Philosophical Transactions of The Royal Society B Biological Sciences, 371 (Jun 5): 1-12.

Greene, J. C. (2005), “The Generative Potential of Mixed Methods Inquiry”, International Journal of Research \& Method in Education, 28(2): 207-211.

Güldemir, O. (2015), Bir Osmanlı Yemek Yazması Kitabüt Tabbahin (Muhammed Kamil), İstanbul: Oğlak Ya.

Güler, S. (2010), “Türk Mutfak Kültürü ve Yeme İçme Alışkanlıkları”, Dumlupınar Ünv. SBE Dergisi, 26 (Nisan): 24-30.

Gürsoy, D. (1995), Yemek ve Yemekçiliğin Evrimi, İstanbul:,B. 1, Sofra.

Hamel, G., Prahalad, C. K. (1996), Geleceği Kazanmak (çev. Zülfü Dicleli), İstanbul: İnkılap Ya. Heller, E. (2000), Arabesk Tılsımlar (çev. Deniz Kırımsoy Kucur), Ankara: İmge Ya.

Henaut, S. Mitchell, J. (2020), Lezzetli Fransa Tarihi: Devrim, Savaş ve Aydınlanma Üzerine Gastronomi Hikayeleri (çev. Gül Tonak), 2020, İstanbul: Say Ya.

Herman, E. S. (1995), Pazarın Zaferi (çev. Zehra Savan), İstanbul: Pınar Ya. No. 176/1.

Hitt, M. A, Ireland R. D., Hoskisson R. E., Strategic Management, Ohio: Third Edition, SouthWestern College Publishing, 1999.

Homeros (2008), İlyada (çev. Azra Erhat, A. Kadir), İstanbul: B. 24,Can Ya. No. 91, Dünya Klasikleri. 17.

https://digital.library.unlv.edu/collections/menus/history-restaurant

https://isparta.ktb.gov.tr/TR-71193/isparta-un-dergisi.html

https://tr.qaz.wiki/wiki/Kebab

https://tr.wikipedia.org/wiki/Kebap

https://www.nisanyansozluk.com/?k=kebap.

https://www.oxfordlearnersdictionaries.com

Hürmüzlü, B. [ed.] (2019), Süleyman Demirel Üniversitesi: Isparta'nın Somut Olmayan

Kültürrel Mirası, Ankara: Desen Ofset A.Ş.

Işın, P. M. (2014), Osmanlı Mutfak İmparatorluğu, İstanbul: Kitap Yayınevi.

Işın, P. M. (2017), Osmanlı Mutfak Sözlüğ̈̈, İstanbul: Kitap Yayınevi.

Işın, P. M. (2018), Avcılıktan Gurmeliğe-Yemeğin Kültürel Tarihi, İstanbul: YKY. 
Sürdürülebilir Rekabette Temel Yetenekler: Isparta Kebapçı Esnafi/Lokanta Isşletmelerinde Araştırma

Kaplan, M. (2010), “Geçmişten Günümüze Isparta Kebapçılarının Stratejik Analizi”, 16-17 Nisan İstanbul 4. Aile İşletmeleri Kongresi Bildiri Kitabı: 173-183.

Kaplan, M. (2021), Dinamik Yetenekler: Rekabet Avantajı ve Çevresel Türbülans, Konya: Eğitim Yayınevi.

Kardüz, A. R. (2001), “Isparta'da Babanın Kebabçısı: Kebabçı Kadir”, http://www.milliyet.com.tr/2001/09/27/pazar/yazkarduz.html

Kaya, G. (2017), Ermeni, Musevi, Rum Evlerinde Pişen Yemekler, İstanbul: Hayy Kitap. Kodaman, B., Babacan, H. [haz.] (1998), Hafız İbrahim Demiralay'ın Hatıratı ve Isparta'da Milli Mücadele ile İlgili Belgeler, Isparta: Göltaş Kültür Ya.

Kut, G. [haz.] (2020), Bilinmeyen Bir Osmanlı Yemek Kitabı: Kitâb-ı Me'kûlât (çevrimyazı. Hüsniye Gülsev Koç), İstanbul: İletişim Ya.

Kvale, S. (1994), “Ten Standard Objections to Qualitative Research Interviews", Journal of Phenomenological Psychology, 25: 147-173.

Lieblich, A., Tuval-Mashiach, R., Zilber, T. (1998), Narrative Research: Reading, Analysis, and Interpretation, Thousand Oaks: Sage.

Markides, C. C., Williamson P.J. (1995), "Related Diversification, Core Competences and Corporate Performance", Strategic Management Journal, 15, 1: 155-174.

Merçil, E. (2000), Türkiye Selçuklularında Meslekler, Ankara: Türk Tarih Kurumu.

Miles, M. B., Huberman, A. M. (1994), An Expanded Source Book: Qualitative Data Analysis, Thousand Oaks: Sage Publications.

Mortan, K., Küçükerman, Ö. (2010), Çarşı, Pazar, Ticaret ve Kapalıçarşı, İstanbul: İş Bankası Ya. No. 1945.

Nasrallah, N. (2007), Annals of the Caliphs' Kitchens: Ibn Sayyār al-Warrāq's Tenth-Century Bağdadi Cookbook, Leiden, Boston: Brill.

Netemeyer R., Bearden W. O., Sharma S. (2003), Scaling Procedures: Issues and Applications, U.S.A: 2nd Edition Sage Publications, Thousand Oaks.

Orel, V., Stolbova, O. V. (1995), Hamito-Semitic Etymological Dictionary: Materials for a

Reconstruction, Leiden, London: E. J. Brill.

Papatya, N. (2007), Kaynak Tabanlı Görüş, Ankara: B. 2, Asil Ya.

Pennisi, E. (1999), "Did Cooked Tubers Spur the Evolution of Big Brains?", Science, 283, 5410

(March 29): 2004-2005.

Prahalad, C. K., Hamel, G. (1990), “The Core Competence of the Corporation”, Harvard Business Review: 79-91.

Ranta, R., Ichijo, A. (2015), Yemek ve Ulusal Kimlik: Gündelik Yaşamdan Küresel Siyasete (çev. Emrullah Ataseven), İstanbul: Ayrıntı Ya.

Rowlett, R. M. (1999), "Fire Use”, Science,, 284, 5415 (April 30): 741.

Standage, T. (2016), İnsanlığın Yeme Tarihi (çev. Gencer Çakır), İstanbul: Maya Kitap.

Şavkar, T. (2000), Osmanlı Mutfağı, İstanbul: Şekerbank.

Şenol, S. (2003), Isparta'nın El Kitabı, Isparta: Göltaş Kültür Merkezi Yayınları.

Şimşek, M. (2020), TKY ve Tarihteki Bir Uygulaması: Ahilik, İstanbul: Hayat Ya. No. 134/21. Teddlie, C., Yu, F. (2007), "Mixed Methods Sampling: A Typology With Examples”, Journal of Mixed Methods Research, 1(1): 77-100. 
Sürdürülebilir Rekabette Temel Yetenekler: Isparta Kebapçı Esnafi/Lokanta Işsletmelerinde Araștirma

Ünsal, A. (2020), İktidarların Sofrası: Yemek, Siyaset ve Simgesellik, İstanbul: Everest Ya. Wrangham, R. (2009), Catching Fire: How Cooking Made Us Human, New York: Basic Books. Wrangham, R. W. vd. (1999), "The Raw and the Stolen”, Current Anthropology, 40, 5 (December): 567-594.

Yaşin, Mehmet (2008), "Isparta'nın tadı tuzu", http://www.hurriyet.com.tr/yazarlar/8299620.asp?yazarid $=45$

Yerasimos, M. (2005), 500 Yıllık Osmanlı Mutfağı, İstanbul: B. 3, Boyut Yayın Grubu. Yin, R. (1994), Case Study Research: Design and Methods. Thousand Oaks: Sage Publications. Yow, V. R. (1994), Recording Oral History: A Practical Guide for Social Scientists, Thousand Oaks: Sage.

\section{II- Makalede Temel Yetenek Tanımı ve Kuramına Dair [Yabancı Yazında] İzlenen Başlıca Kaynaklar}

Barney, J. A. (1997), Gaining and Sustaining Competitive Advantage, Mass: Addison-Wesley Publishing Company, Inc.

Cho, W. (1996), A Case Study: Creating and Sustaining Competitive Advantage Through An Information Technology Application in the Lodging Industry, [Diss] Virginia Polytechnic Institute.

Collis, D. J. (1994), “Research Note: How Valuable Are Organizational Capabilities?", Strategic Management Journal, 15: 143-152.

Collis, D. J., Montgomery, C. A. (1995). "Competing on Resources: Strategy in the 1990's." Harvard Business Review, 118-128.

Grant, R. M. (1991), "The Resource-Based Theory of Competitive Advantage: Implications for Strategy Formulation", California Management Review: 114-135.

Hall, R. (1992), "The Strategic Analysis of Intangible Resources", Strategic Management Journal, 13: 135-144.

Hall, R. (1993), "A Framework Linking Intangible Resources and Capabilities to Sustainable Competitive Advantage", Strategic Management Journal, 14: 607-618.

Hamel, G., Heene, A. [edt.] (1994), Competence-based Competition A. New York: Wiley \& Sons içinde; Klein, J.A., Hiscocks, P.G. (1994), "Competence-based Competition: A Practical Toolkit."

Hitt, M. A., Ireland, R. D. (1986), "Relationships Among Corporate Level Distinctive Competencies, Diversification Strategy, Corporate Structure and Performance", Journal of Management Studies, 23 (4): 401-416.

Lado, A. A., Boyd, N. G., Wright, P. (1992), "A Competency-Based Model of Sustainable Competitive Advantage: Toward A Conceptual Integration”, Journal of Management, 18 (1): 77 91.

Hood, N., Vahlne, J. E. [edt] (1998), Strategies in Global Competition,London: Croom Helm içinde; Doz, P., Prahalad, C. K, "Quality of Management : An Emerging Source of Global Competitive Advantage": 345-369.

Naugle, D. G., Davies, G. A. (1987), "Strategic-Skill Pools and Competitive Advantage", Business Horizons: $35-42$.

Haskell, P. G. (1990), The Prudent Person Rule for Trustee Investment and Modern Portfolio Theory, 69 N.C. L. Rev. 87: 87-111. 
Sürdürülebilir Rekabette Temel Yetenekler: Isparta Kebapçı Esnafi/Lokanta İşletmelerinde Araștirma

Prahalad, C. K., Hamel, G. (1990). "The Core Competence of the Corporation", Harvard Business Review: 79-91.

Reed, R., DeFillippi, R. J., (1990), “Casual Ambiguity, Barriers to Imitation and Sustainable Competitive Advantage", Academy of Management Review, 15 (1): 88-102.

Schulz, W. C. (1993), Skill Based Strategy and Entrepreneurial Leadership: How Individual and Corporate Entrepreneurs Create Value, [Diss] University of Georgia, Ann Arbor: UMI.

Simmons, R. (1990), "The Role of Management Control Systems In Creating Competitive Advantage: New Perspectives", Accounting Organizational and Society, 15 (1/2): 127-143.

Snow, C. C., Hrebiniak, L. G. (1980), "Strategy, Distinctive Competence, and Organizational Performance", Administrative Science Quarterly, 25: 317-336.

Stalk, G., Evans, P., Shulman, L.E. (1992), "Competing On Capabilities: The New Rules of Strategy", Harvard Business Review: 57-69.

Tampoe, M. (1994), “Exploiting the Core Competences of Your Organization”, Long Range Planning, 27 (4): 66-77.

Ventrice-Kish, L. (1994), "Predicting Business Failure in the Food Service Industry", [Thesis] Virginia Polytechnic Institute. 
Sürdürülebilir Rekabette Temel Yetenekler: Isparta Kebapçı Esnafi/Lokanta İşletmelerinde Araștırma

Ekler: Fotoğraflar

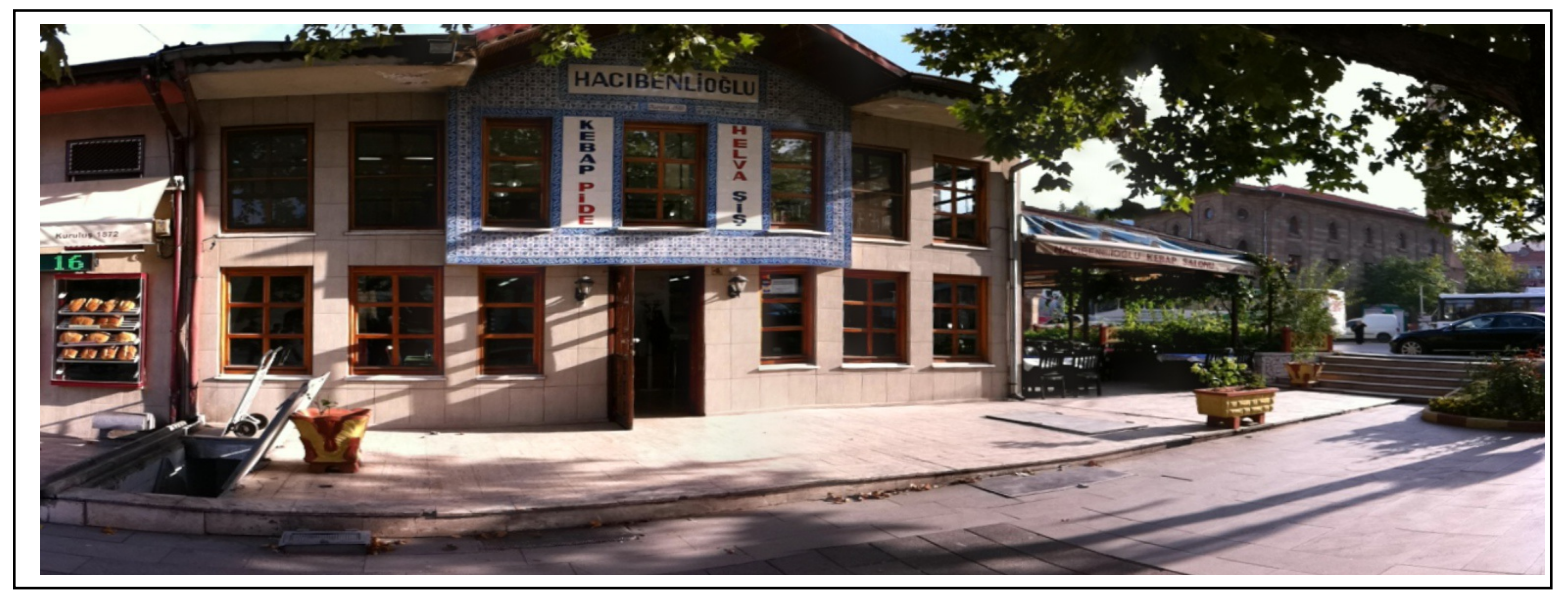

Foto 1: Kebapçı Hacıbenlioğlu (2020)

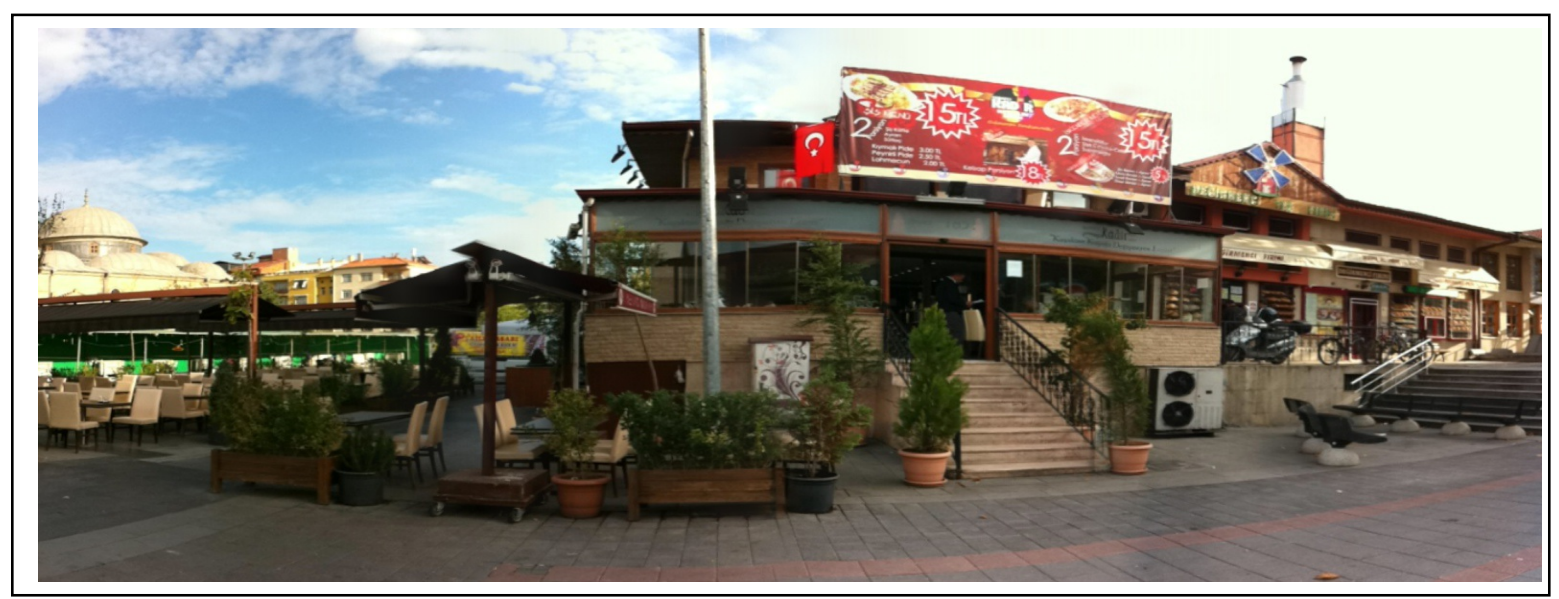

Foto 2: Kebapçı Kadir (2020)

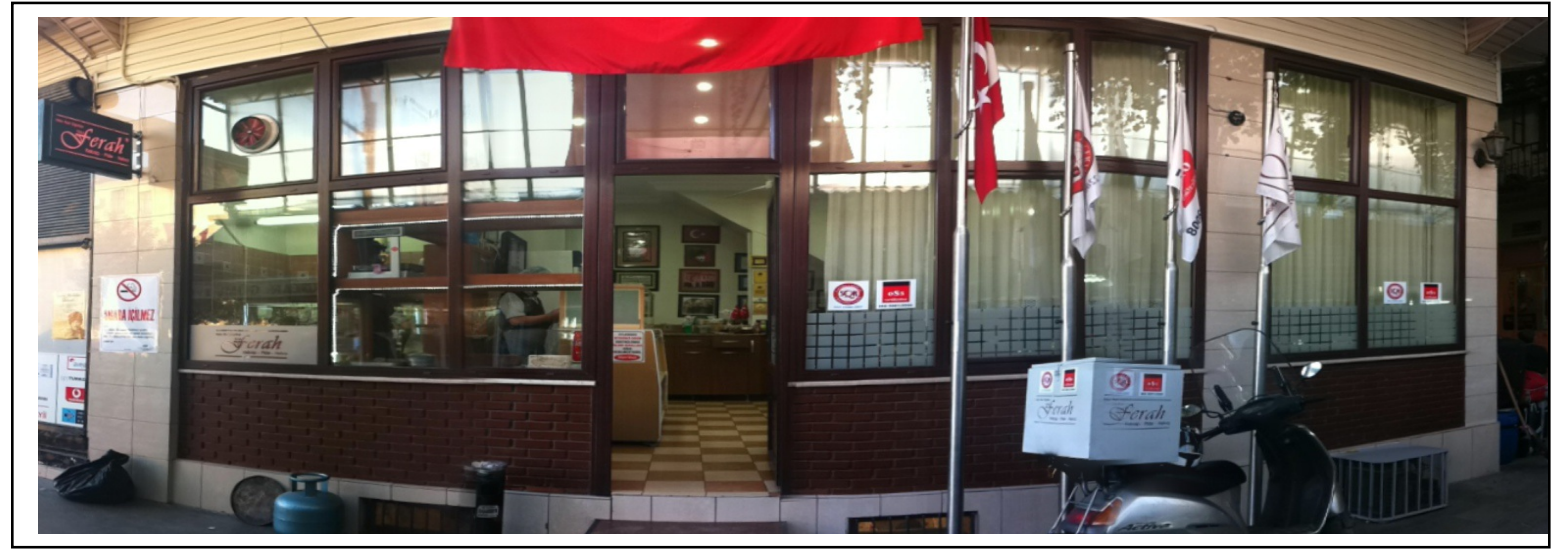

Foto 3: Kebapçı Ferah (2020) 
Sürdürülebilir Rekabette Temel Yetenekler: Isparta Kebapçı Esnafi/Lokanta İşletmelerinde Araștırma

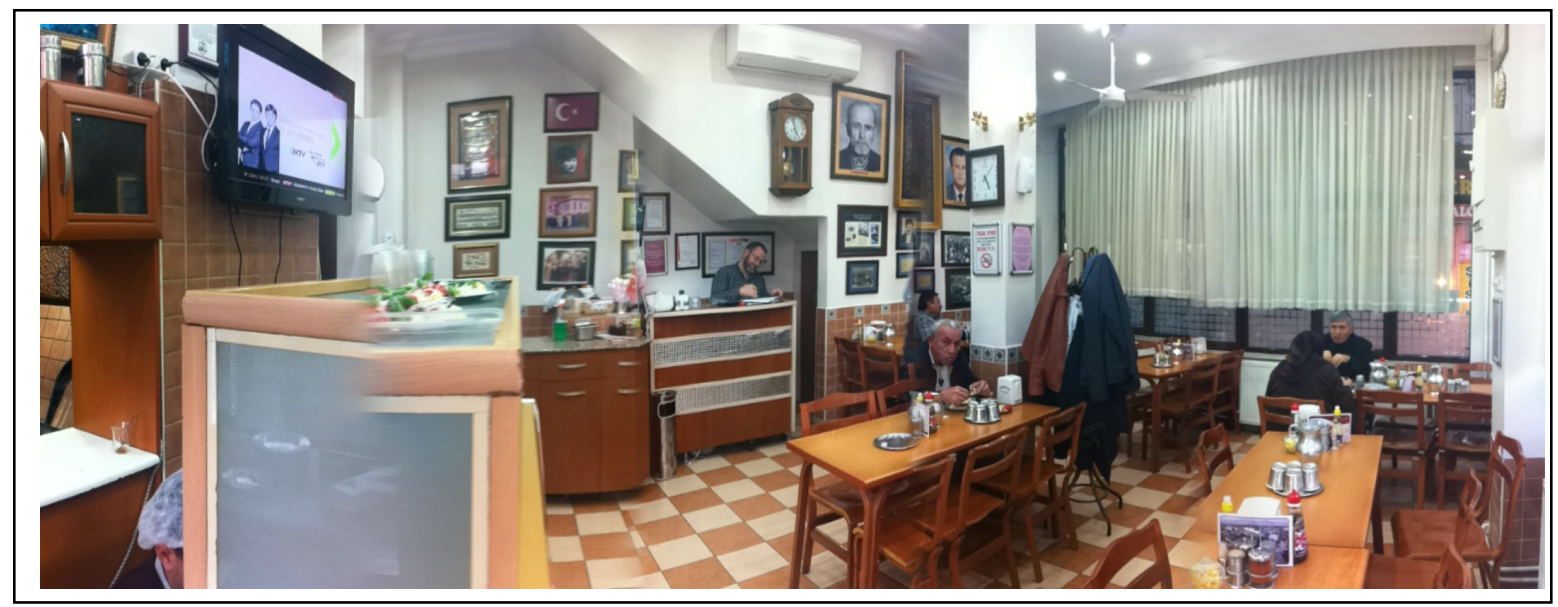

Foto 4: Kebapçı Ferah (2020)

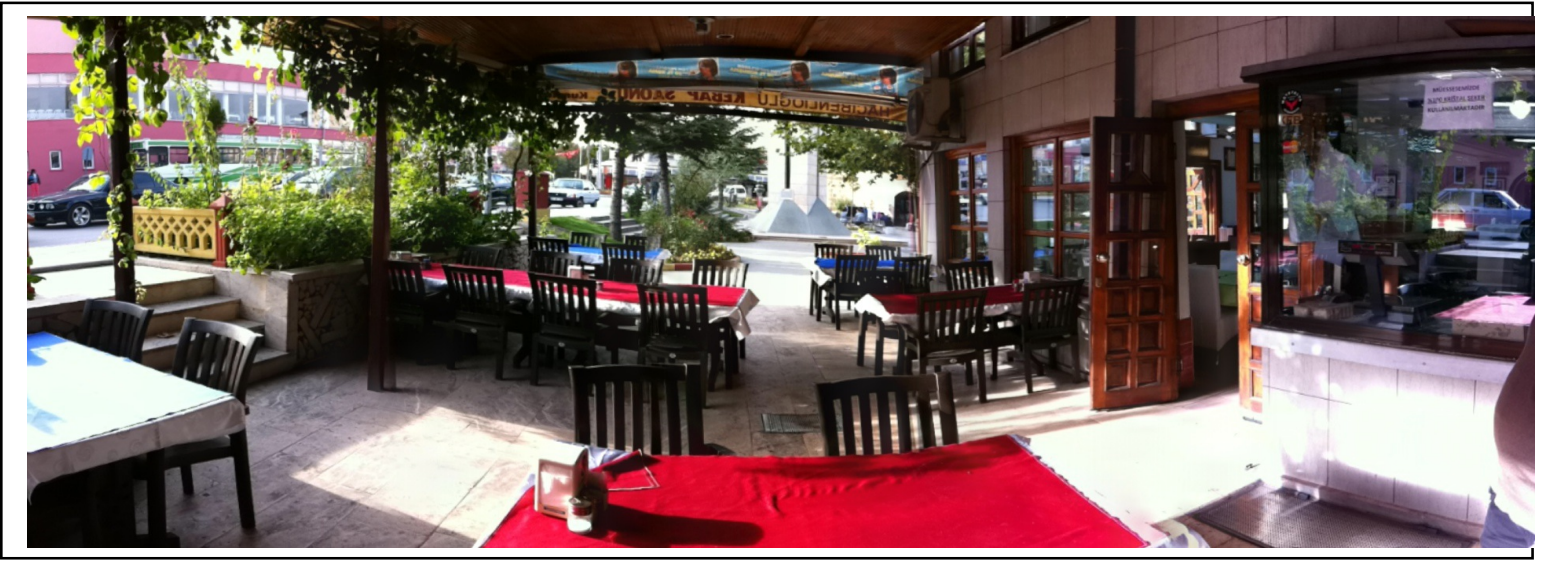

Foto 5: Kebapçı Hacıbenlioğlu (2020)

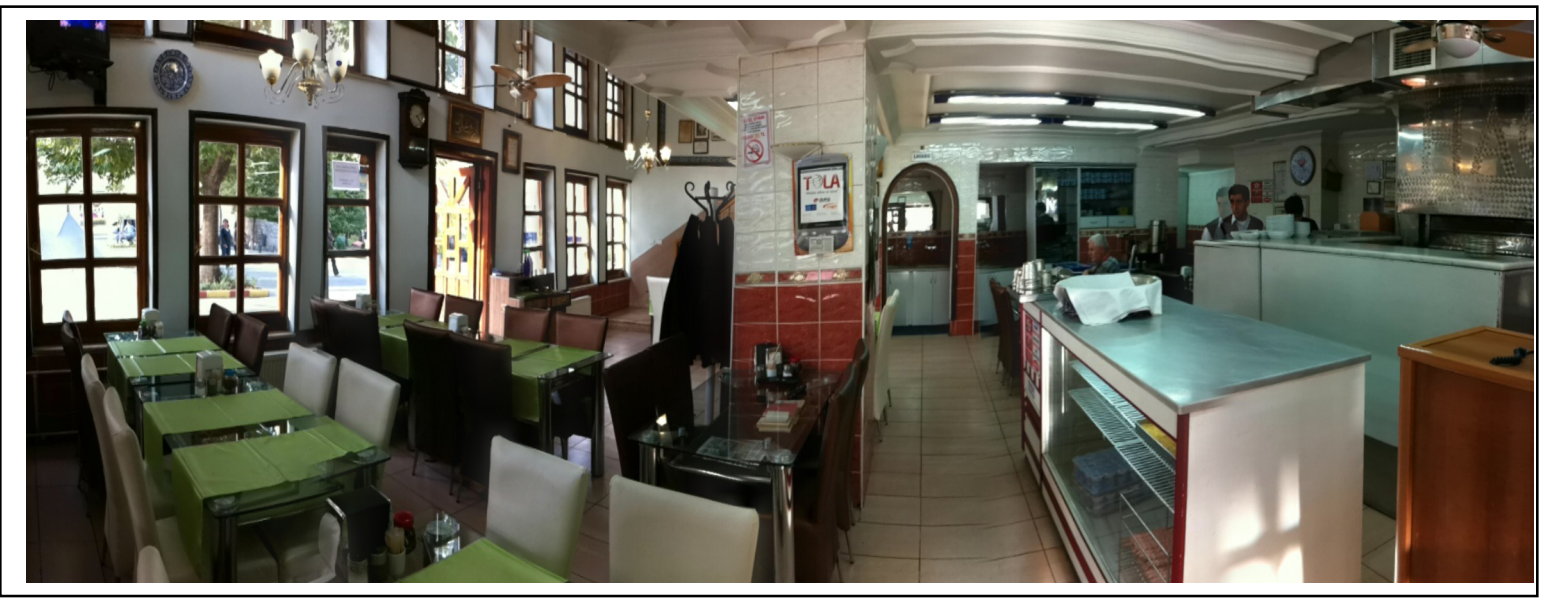

Foto 6: Kebapçı Hacıbenlioğlu (2020) 